University of Pennsylvania Carey Law School

Penn Law: Legal Scholarship Repository

Faculty Scholarship at Penn Law

Fall 2005

\title{
The Fair Value of Cornfields in Delaware Appraisal Law
}

Lawrence Hamermesh

Widener University

Michael L. Wachter

University of Pennsylvania Carey Law School

Follow this and additional works at: https://scholarship.law.upenn.edu/faculty_scholarship

Part of the Business Organizations Law Commons, Corporate Finance Commons, and the Law and Economics Commons

\section{Repository Citation}

Hamermesh, Lawrence and Wachter, Michael L., "The Fair Value of Cornfields in Delaware Appraisal Law" (2005). Faculty Scholarship at Penn Law. 72.

https://scholarship.law.upenn.edu/faculty_scholarship/72

This Article is brought to you for free and open access by Penn Law: Legal Scholarship Repository. It has been accepted for inclusion in Faculty Scholarship at Penn Law by an authorized administrator of Penn Law: Legal Scholarship Repository. For more information, please contact PennlawIR@law.upenn.edu. 


\title{
The Fair Value of Cornfields in Delaware Appraisal Law
}

\author{
Lawrence A. Hamermesh* and Michael L. Wachter ${ }^{* *}$
}

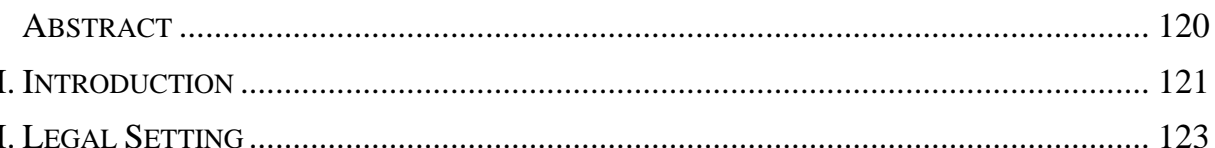

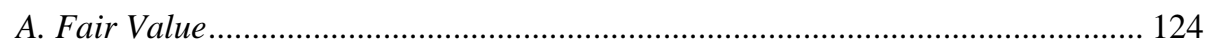

$B$. The Exclusion of Value Arising from the Merger and the

Language of Weinberger................................................................................ 126

C. Appraisal Remedy as a Claim Distinct from Breach of

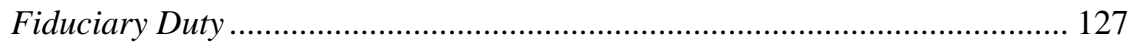

D. Types of Mergers Where the Appraisal Remedy is Available ............................. 128

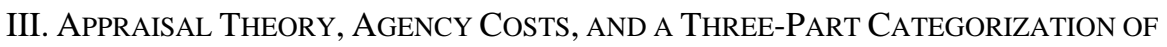

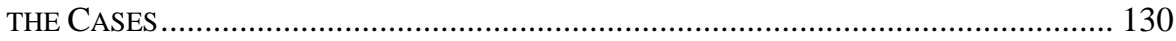

A. Appraisal Theory: Problem to be Solved and Alternative

Concepts of Fair Value ............................................................................... 130

B. Three Alternative Measures of Fair Value ...................................................... 132

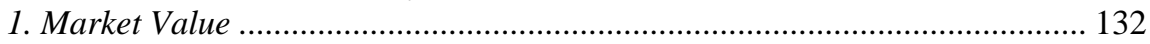

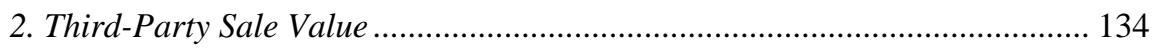

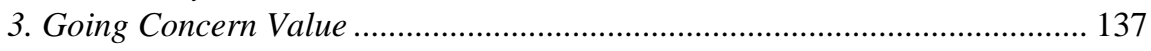

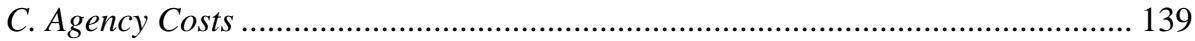

D. Three Prototypical Case Patterns …................................................................ 141

1. Category 1: Merger Involving a Third Party............................................... 141

2. Category 2: Squeeze-Out Merger Where the Company Will

Continue to be Operated as Before the Merger......................................... 143

3. Category 3: Squeeze-Out Merger Where the Company Will

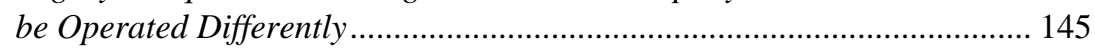

IV. Delaware Case LaW Corroborates the Proposed TheOretical

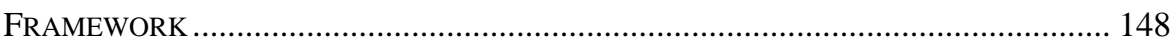

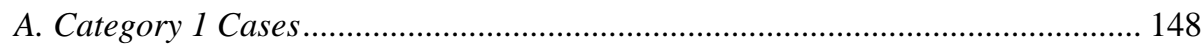

1. Gains Arising from the Merger: Synergistic/Combinatorial

* Ruby R. Vale Professor of Corporate and Business Law, Widener University School of Law; Director, Widener Institute of Delaware Corporate Law.

** William B. Johnson Professor of Law and Economics, University of Pennsylvania Law School; Co-Director, Institute for Law \& Economics at the University of Pennsylvania. The authors gratefully acknowledge the contribution of the criticisms and suggestions made by Michael Klausner, Bruce Silverstein, Edmund Kitch, and other participants in the April 15, 2005 Roundtable of the Institute for Law \& Economics. The authors also thank J. Travis Laster, Esquire, of Abrams \& Laster LLP, for sharing his compilation of Delaware appraisal case law. 
2. Gains Arising From the Merger: Acquirer's New Business

Plans

3. The Role of Third-Party Sale Value.

B. Category 2 Cases: Controlling Shareholder Squeeze-Out

Merger/"Fair Value” Equals Going Concern Value Absent

Planned Change of Business, and Not Hypothetical Third-

Party Sale Value. 154

1. Kirby: The Foundational Case.... 155

2. Kleinwort: Satisfying Conflicting Demands for Liquidity 156

3. Borruso: Reconsolidating a Failing Subsidiary.... 156

4. Ng: Achieving More Favorable Tax Treatment. 157

5. Gholl: Changing Both the Controller and the Manager. 157

C. Category 3 Cases: Controlling Shareholder Squeeze-Out

Merger/"Fair Value" Equals Going Concern Value Under

Controlling Shareholder's Post-Merger Management Plans 158

1. Inclusion of Usurped Business Opportunities....

2. Excluding Past or Projected Expenses

3. Including Combinatorial Merger Gains Not Dependent Upon the Consummation of the Merger

D. Doctrinal Refinement of the Treatment of Merger-Related

Gains in Assessing "Fair Value". 164

V. CONCLUSION

\section{ABSTRACT}

The Delaware Supreme Court's opinions in Weinberger and Technicolor have left a troublesome uncertainty in defining the proper approach to the valuation of corporate shares. That uncertainty-increasingly important as going private mergers become more frequent-can be resolved by a blend of financial and doctrinal analysis. The primary problem, the potential opportunism by controlling shareholders in timing going private mergers, can be addressed by a more complete understanding of corporate finance. The definition of fair value must include not only the present value of the firm's existing assets, but also the future opportunities to reinvest free cash flow, including reinvestment opportunities identified, even if not yet developed, before the merger. This issue has been incompletely articulated by the courts. On the other hand, value created by the merger that can only be achieved by means of the merger itself-such as reduced costs of public company compliance-should not be included in determining fair value. We also show that except in the case of acquisitions by third parties (where actual sale value, minus synergies, is a useful measure of fair value), hypothetical third-party sale value does not and should not ordinarily be taken as a measure of fair value. 


\section{INTRODUCTION}

The Weinberger ${ }^{1}$ decision in 1983 revolutionized appraisal law, and like many revolutions left an array of messy puzzles that persist to this day. One was its dictum concerning the statutory prohibition against including gains from mergers in calculating the fair value of the firm in appraisal. ${ }^{2}$ Despite the literal clarity and breadth of the statutory prohibition, the court opined that the exclusion is "a very narrow exception to the appraisal process, designed to eliminate use of . . . projections of a speculative variety relating to the completion of the merger." ${ }^{3}$ It was not until Technicolor ${ }^{4}$ that both the Delaware Court of Chancery and the Delaware Supreme Court addressed the Weinberger ruling and its tension with the literal language of the statutory exclusion. While the court of chancery attempted to resolve that tension, ${ }^{5}$ the supreme court rejected the Chancellor's reasoning and reaffirmed its earlier ruling, without providing much guidance for resolving the uncertainty as to the scope of the statutory valuation exclusion. ${ }^{6}$

The issue is a significant one. Appraisal is becoming an increasingly important remedy ${ }^{7}$ in light of the growth of going private mergers, ${ }^{8}$ the fact that appraisal is the exclusive remedy in short-form mergers after Glassman, ${ }^{9}$ and the growing use of tender offers as the mechanism of choice for completing a merger. ${ }^{10}$ In all these cases, it is the squeeze-out cash merger (along with the mergers involving a close corporation) that gives rise to most of the appraisal cases. What then to make of the supreme court's ruling in Weinberger? What types of gains that occur after such a merger can be included in valuing a firm in appraisal? Is the line drawn between "speculative" and "nonspeculative" gains, as the court suggested, ${ }^{11}$ or should the line be drawn differently?

The issue has not received much concentrated attention from academic researchers. Perhaps the main exception, for our purposes, is Professor Coffee's 1996 article. ${ }^{12}$ In that article he stated that in squeeze-out mergers, gains resulting from the controller's use of

1. Weinberger v. UOP, Inc., 457 A.2d 701 (Del. 1983).

2. Id. at 713 (interpreting the Delaware appraisal statute); DEL. CoDE ANN. tit. 8, § 262 (2001).

3. Weinberger, 457 A.2d at 713.

4. Cede \& Co. v. Technicolor, Inc., 684 A.2d 289 (Del. 1996).

5. Cede \& Co. v. Technicolor, Inc., No. 7129, 1990 WL 161084 (Del. Ch. Oct. 19, 1990), rev'd, 684 A.2d 289 (Del. 1996).

6. Technicolor, 684 A.2d at 297; see infra Part IV.A.1.

7. Our rough count of appraisal opinions from the Delaware courts in the 22 years since 1983, when Weinberger was decided, reveals a total of 46 opinions, of which 11 were issued since January 1, 2004.

8. See Joshua M. Koenig, A Brief Roadmap to Going Private, 2004 ColuM. Bus. L. ReV. 505, 506 (2004).

9. Glassman v. Unocal Exploration Corp., 777 A.2d 242, 248 (Del. 2001) (holding that "absent fraud or illegality, appraisal is the exclusive remedy available to a minority stockholder who objects to a short-form merger”).

10. See, e.g., Ronald J. Gilson \& Jeffrey N. Gordon, Controlling Controlling Shareholders, 152 U. PA. L. REV. 785, 825 (2003) (noting the “doctrinal anomalies posed by the freeze-out, tender offer strategy”); Guhan Subramanian, Post-Siliconix Freeze-Outs: Theory, Evidence and Policy (Harvard Law \& Econ. Discussion Paper No. 472, 2004), available at http://ssrn.com/abstract=530284 (noting significant increase in use of tender offer/short-form merger freeze-out technique).

11. Technicolor, 684 A.2d at 296-300.

12. John C. Coffee, Jr., Transfers of Control and the Quest for Efficiency: Can Delaware Law Encourage Efficient Transactions While Chilling Inefficient Ones?, 21 DEL. J. CORP. L. 359 (1996). 
inside information should be included in calculating the fair value of the firm, while other merger gains should not. ${ }^{13}$ In concluding, Coffee said that the courts should be attentive to the "hidden cash flows" that result from inside information. ${ }^{14}$ Although Coffee's analytical structure has been of some help to the courts, ${ }^{15}$ the fact that the recommendation turns on hidden cash flows renders it less useful in its actual application.

In addition, there is a small literature that touches on a broader issue: whether the appropriate standard in appraisal should be going concern value (the standard applied by the court) or one of two alternatives, third-party sale value or market value. Commentators have weighed in on all sides of this debate. ${ }^{16}$

In this Article we provide a rationale for the courts' use of going concern value. We also propose a resolution of the dilemma the court faces in deciding which gains that follow a merger should be included in the fair value of the firm and which gains should not. Our rule is broader than the one proposed by Coffee and, we believe, is easier to use. In several instances, in fact, we believe that our approach simply echoes settled judicial articulations of valuation standards. In other cases, however, we believe that the case law, while not inconsistent with our approach, has not fully developed appropriate doctrinal guidance.

In Part III we briefly review the relevant rules governing appraisal, drawing particular attention to the difficulties posed by the Delaware Supreme Court's dictum in Weinberger. We then provide a theoretical justification for the use of going concern value as the appropriate standard for valuation. In doing so we develop a three-part categorization that spans most of the appraisal case law.

The first category involves mergers where the squeeze-out is a result of the purchase of the firm by a third party. In resolving cases in this category, the courts have discussed and used, in different ways, the third-party sale price as the critical piece of information in valuing the firm. For this category we propose a rule that justifies the use of third-party sale value as a critical input in some cases but not in others. The second category involves a squeeze-out merger where the controller squeezes out the minority but otherwise conducts the business of the corporation in a largely unchanged way. We believe that most appraisal cases fall into this category, and it is this category of cases that best illustrates why going concern value needs to be the standard of appraisal valuation. The third category of cases is the most difficult and is where the dictum in

13. Id. at 416 ("[T] $[\mathrm{T}$ he most sensible line is to deem synergistic gains as a necessary element of fair value only in the case of insider buyouts and squeeze-outs and only when the buyer had access to the target corporation's confidential business plans and projections in framing its proposal.”) (emphasis added).

14. Id. at 420-21.

15. See ONTI Inc. v. Integra Bank, 751 A.2d 904, 911 (Del. Ch. 1999) (rejecting Coffee’s conclusion).

16. E.g., Victor Brudney, Equal Treatment of Shareholders in Corporate Distributions and Reorganizations, 71 CAL. L. REV. 1072 (1983) (urging a rule of proportionate sharing of merger gains among both controlling and non-controlling shareholders); John C. Coates IV, "Fair Value" as an Avoidable Rule of Corporate Law: Minority Discounts in Conflict Transactions, 147 U. PA. L. REV. 1251, 1351 (1999) (recommending use of acquisition "reference" values with burden on transaction proponent to validate exclusion of impermissible synergistic elements); Barry M. Wertheimer, The Shareholders' Appraisal Remedy and How Courts Determine Fair Value, 47 DuKE L.J. 613, 674-75 (1998) (advocating third-party sale value standard); Bruce L. Silverstein, Judicial Valuation of Stock of a Delaware Corporation: The Legal Concept of "Fair Value” (Apr. 20, 2004) (unpublished manuscript, on file with authors) (suggesting adoption of a thirdparty sale value standard). 
Weinberger is most relevant. Here we propose an alternative standard that follows directly from applying finance theory to the problem.

In Part IV, we review the case law applicable to our three-part categorization. By analyzing the interaction of finance theory and the large body of case law, we believe that our approach provides an understanding of the key valuation parameters that are important in applying the otherwise confusing dictum in Weinberger.

This Article has both positive and normative aspects. We view the paper as primarily positive in that we attempt to provide both a rationale and a coherent structure to existing Delaware case law. We make no claims that the current law is the best appraisal law possible, only that some of the current inconsistencies can be reconciled in a manner that is consistent with the Delaware General Corporation Law (DGCL) and the main court cases. At the same time, the paper is hardly devoid of normative judgments. On the one hand, we do not view as normative the assertion that the DGCL's appraisal remedy can be understood as requiring a Pareto-superior solution. Quite to the contrary, the law is quite explicit on this point. On the other hand, the Delaware Supreme Court's utterances, as far back as Tri-Continental and more recently in Weinberger and Technicolor, have to be normatively interpreted because the opinions give rise to conflicting interpretations. For example, some would read Technicolor as allowing or even encouraging an appraisal rule that would be indistinguishable from a third-party sale rule. We explain our contrary view by turning first to the legal setting in which the issue arises.

\section{LEGAL SETTING}

The legal prescription in Delaware for determining share value derives from the appraisal rights statute, section 262 of the Delaware General Corporation Law. ${ }^{17}$ Subsection (h) of that statute sets forth the relevant parameters for determining value in appraisal proceedings:

[The court of chancery] shall appraise the shares, determining their fair value exclusive of any element of value arising from the accomplishment or expectation of the merger or consolidation, together with a fair rate of interest, if any, to be paid upon the amount determined to be the fair value. In determining such fair value, the Court shall take into account all relevant factors. 18

Section 262 provides four important instructions, which we first summarize and then explore in greater detail. The first instruction is that any shareholders who have not voted in favor of the merger and have otherwise complied with the statute's procedural requirements are entitled to an award of the "fair value" for their shares. ${ }^{19}$ The statute, however, does not provide any further explicit definition of "fair value." The second instruction is that "fair value," whatever it does mean, does not include any "element of value arising from the accomplishment or expectation of the merger or consolidation." 20

\footnotetext{
17. Del. Code ANN. tit. 8, § 262 (2005).

18. Id.

19. Id. § 262(a).

20. Id.
} 
The exact meaning of this exclusion-and specifically whether it should be read broadly or narrowly-became a major unresolved issue in appraisal cases after the Delaware Supreme Court spoke directly to the issue in Weinberger, ${ }^{21}$ but in a manner that opened the interpretation problem rather than closing it. The third point of instruction is that the appraisal remedy is entirely about determining and awarding "fair value," and evidence with respect to a breach of the fiduciary duty of loyalty is largely irrelevant to that task. ${ }^{22}$ Finally, the appraisal remedy is available in only limited types of cases. The statutory choice of contexts in which appraisal rights are conferred determines the special problems that emerge in determining the meaning of "fair value."

\section{A. Fair Value}

"Fair value" is a legal term. How is it to be interpreted? The legal explanation of fair value's core meaning dates back more than half a century to Tri-Continental Corp. v. Battye, a 1950 case in which the Delaware Supreme Court stated: "The basic concept of value under the appraisal statute is that the stockholders are entitled to be paid for that which has been taken from them, viz. his proportionate interest in a going concern.”23 Other cases have characterized this concept in a shorthand way as "going concern value," 24 while still other cases describe the concept as the "true" or "intrinsic" value of the stock that has been taken by the merger. ${ }^{25}$ Although these concepts are not completely unhelpful in selecting appropriate finance methods for measuring fair value, there is considerable room for ambiguity. For example, what is the "intrinsic" value of the stock, a term that has no precise counterpart in finance theory?

For decades prior to 1983, courts measured the intrinsic value of stock using the Delaware block method. ${ }^{26}$ In that method, the court determined, where possible, the value of the company's assets, the market price of its stock, and the value of its earnings. These components were each assigned a particular weight that varied with the circumstances of the case. ${ }^{27}$ The sum of the weighted components was the intrinsic value or fair value of the stock. Since the capital asset pricing model was not developed until

21. Weinberger v. UOP, Inc., 457 A.2d 701, 713 (Del. 1983).

22. See infra Part II.C.

23. Tri-Cont'l Corp. v. Battye, 74 A.2d 71, 72 (Del. 1950).

24. See infra note 54.

25. Chicago Corp. v. Munds, 172 A. 452, 455-56 (Del. Ch. 1934); see also Roessler v. Sec. Sav. \& Loan Co., 72 N.E.2d 259, 260 (Ohio 1947).

26. See, e.g., Poole v. N.V. Deli Maatschappij, 243 A.2d 67, 69 (Del. 1968); see also Walter S. Cheesman Realty Co. v. Moore, 770 P.2d 1308, 1311 (Colo. Ct. App. 1988); Richardson v. Palmer Broadcasting, 353 N.W.2d 374, 378 (Iowa 1984); In re Valuation of Common Stock of Libby, McNeill \& Libby, 406 A.2d 54, 60 (Me. 1979); Leader v. Hycor, Inc., 479 N.E.2d 173, 178-79 (Mass. 1985); Columbia Mgmt. Co. v. Wyss, 765 P.2d 207 (Or. 1988); Blasingame v. Am. Materials, Inc., 654 S.W.2d 659, 665 (Tenn. 1983); General Valuation Standards, 2-36 DEL. CoRP. LAW \& PRACTICE § 36.07 (MB) (2005) (stating that the courts' insistence on the use of the block method "arose out of [their] desire for an analytical framework in which the valuation judgments of court-appointed appraisers could be identified and reviewed by the courts") (citing Jacques Coe \& Co. v. Minneapolis-Moline Co., 75 A.2d 244, 246 (Del. Ch. 1950)).

27. Weinberger v. UOP, Inc., 457 A.2d 701, 712 (Del. 1983) ("This means that the so-called 'Delaware block' or weighted average method was employed wherein the elements of value, i.e., assets, market price, earnings, etc., were assigned a particular weight and the resulting amounts added to determine the value per share. This procedure has been in use for decades.”). See also In re Gen. Realty \& Util. Corp., 52 A.2d 6, 14-15 (Del. Ch. 1947). 
the 1960 s, ${ }^{28}$ the court's ad hoc approach was not strictly dominated by anything finance theory had to offer until then.

In Weinberger, however, the Delaware Supreme Court abandoned insistence upon the block method, and instead stated that the methodology to be used for measuring fair value should be generally accepted techniques used in the financial community. ${ }^{29}$ As the supreme court's direction has been applied over the years since Weinberger, the court of chancery has increasingly come to favor "discounted cash flow" (DCF) analysis of modern finance theory as the core approach to measuring value. ${ }^{30}$ In this theory, the value of an asset is the present value of the discounted stream of future free cash flows that the asset can generate. ${ }^{31}$ The discount rate used in this method is one of several mean/variance theories of discount rates, the most well-known being the capital asset pricing model. ${ }^{32}$ We take the timing of the Weinberger decision as well as subsequent Delaware case law to mean that the technique to be applied whenever possible is indeed the technique that generations of MBAs have been taught as the core approach to valuing assets.

The finance theory, however, is highly stylized and dependent on a host of assumptions that are rarely met, and the theory is in fact weakest in those areas where appraisal is available. ${ }^{33}$ The result is competing definitions of fair value. ${ }^{34}$ For example,

28. The original published papers on the capital asset pricing model are William F. Sharpe, Capital Asset Prices: A Theory of Market Equilibrium under Conditions of Risk, 19 J. FIN. 425 (1964), and John Lintner, The Valuation of Risky Assets and the Selection of Risky Investments in Stock Portfolios and Capital Budgeting, 47 REV. ECON. \& STAT. 13 (1965).

29. Weinberger, 457 A.2d at 712. ("[T]o the extent [the Delaware block method] excludes other generally accepted techniques used in the financial community and the courts, it is now clearly outmoded. It is time we recognize this in appraisal and other stock valuation proceedings and bring our law current on the subject.”).

30. See, e.g., Grimes v. Vitalink Commc'ns Corp., Civ. A. No. 12334, 1997 Del. Ch. LEXIS 124, at *3 (Del. Ch. Aug. 26, 1997) (observing that the DCF approach is "increasingly the model of choice for valuations in this Court”); Ryan v. Tad's Enters., Inc., 709 A.2d 682, 702 (Del. Ch. 1996) (“The discounted cash flow valuation model is well-established and accepted in the financial community.”), aff'd, 693 A.2d 1082 (Del. 1997).

31. The ONTI court stated:

The DCF model entails three basic components: an estimation of net cash flows that the firm will generate and when, over some period; a terminal value equal to the future value, as of the end of the projection period, of the firm's cash flows beyond the projection period; and finally a cost of capital with which to discount to a present value both the projected net cash flows and the estimated terminal or residual value.

ONTI, Inc. v. Integra Bank, 751 A.2d 904, 917 (Del. Ch. 1999) (quoting Cede \& Co. v. Technicolor, Inc., Civ. A. No. 7129, 1990 Del. Ch. LEXIS 259, at*24 (Del. Ch. Oct. 19, 1990)). The terminal value can be estimated in a number of different ways. The court typically assigns the term DCF analysis to one particular estimate of the terminal value; namely the Gordon growth model where the terminal value is estimated by discounting to the present value the last period free cash flow divided by the difference between the market capitalization or discount rate minus the assumed future growth rate in free cash flow. However, the DCF analysis, as the term is used in modern finance, also includes methods where the terminal value is estimated by capitalizing the last period earnings or book value by using either a stock market based price-earnings multiple or a multiple of book value. Richard A. Brealey et AL., PRinCIPLES OF CORPORATE FinANCE 509-11 (8th ed. 2005).

32. BREALEY ET AL., supra note 31, at 190.

33. The capital asset pricing model applies only to publicly traded companies and thus does not offer a theory for close corporations. In addition, the theory assumes stock trades in liquid capital markets, which rules out closely held but publicly traded stock. The courts' use of DCF analysis in evaluating close corporation shares thus depends on the use of alternative methods for estimating the corporation's cost of equity capital (for 
can market prices be used as the best available measure of firm value? After all, finance theory has not only canonized DCF, but the efficient capital market hypothesis as well. ${ }^{35}$ Alternatively, could third-party sale value be used in valuing the company? After all, the definition of value used by economists is a version of third-party sale value-that is, the opportunity cost of the asset in its next best use. ${ }^{36}$

One obvious problem with using third-party sale value, at least without modification, is that it includes elements of value created by the merger that would not otherwise exist. This inclusion conflicts with the statutory mandate that "any element of value arising from the accomplishment or expectation of the merger or consolidation" must be excluded. ${ }^{37}$ And, in fact, case law has held consistently that third-party sale value, to the extent that it includes synergies created by the merger, cannot be used as a measure of fair value. ${ }^{38}$

\section{B. The Exclusion of Value Arising from the Merger and the Language of Weinberger}

Although the statute states that value arising from the expectation or accomplishment of the merger cannot be included in appraisal, the meaning of that language was thrown into some confusion by the supreme court's decision in Weinberger. The court specifically held that in determining fair value based on all relevant factors:

[o]nly the speculative elements of value that may arise from the "accomplishment or expectation" of the merger are excluded. We take this to be a very narrow exception to the appraisal process, designed to eliminate use of pro forma data and projections of a speculative variety relating to the completion of a merger. But elements of future value, including the nature of the enterprise, which are known or susceptible of proof as of the date of the merger and not the product of speculation, may be considered. ${ }^{39}$

This language set off a debate that remains unresolved to this day, particularly since, if read broadly, it may conflict with the statutory mandate excluding values arising from the completion of a merger. What is to be made of the last sentence, which presumably provides the guidance as to what elements of value can be included? Standing alone, the sentence makes good sense and provides excellent guidance. In the context of the paragraph, however, it is puzzling.

Clearly, this critical last sentence in Weinberger is referring to the future value of

example, by reference to observations of trading in shares of comparable companies, the shares of which trade in liquid markets).

34. The "internal rate of return" (IRR) method used in finance is not one of the competitors. The method is often used in finance to determine whether to proceed with a particular investment or asset purchase. However, it is structured to answer the question of whether the rate of return from the investment or purchase is greater than the investor's hurdle or discount rate. Hence, the IRR method does not provide an estimate of the value of an investment or asset.

35. Efficient markets and the capital asset pricing model are taught in all major finance textbooks. See BREALEy ET AL., supra note 31; STEVEN A. Ross ET AL., CorPORATE FinANCE (7th ed. 2005).

36. BREALEY ET AL., supra note 31, at 16 .

37. DEL. CODE ANN. tit. 8, § 262(h) (2005).

38. See infra Part IV.A.1.

39. Weinberger v. UOP, Inc., 457 A.2d 701, 713 (Del. 1983). 
the enterprise that is the target of the merger. More specifically, it is not referring to the new corporation or combination that will result from the merger. Rather, the language of Weinberger seems to establish the nature of the enterprise at the time of the merger as the key parameter in the valuation exercise. Defining "the nature of the enterprise," however, is not a mechanistic task. Although we address this issue in more detail below, a few introductory comments are useful.

It is well accepted that the value of a corporation and its assets depends on the future free cash flows that are generated. ${ }^{40}$ Fair value is thus forward-looking. Most obviously, the concept of fair value takes account of the current assets of the corporation and the free cash flow generated by those assets. Perhaps less obviously, fair value must also take account of the corporation's reinvestment opportunities as well. Most corporations are not closed end, wasting asset enterprises, and estimates of future free cash flows almost invariably involve projected returns on reinvestment of future free cash flows. The "nature of the enterprise" is therefore not defined solely by its current asset stock, but by the current assets and those assets it is likely to acquire as part of its current corporate policy.

The problem that arises in some of the most difficult appraisal cases is that reinvestment opportunities that inhere in the corporation are taken by the controlling shareholder as a result of a merger cashing out the minority shareholders. From a legal standpoint, the controller's actions may or may not constitute a breach of the duty of loyalty in the form of a taking of a corporate opportunity. From a finance perspective, however, when such opportunities are known at the date of the merger and are part of the corporate policy options the firm is planning to exploit, they should be included as part of the value of the firm. This brings us to the third issue, the intersection of appraisal and breach of the duty of loyalty.

\section{Appraisal Remedy as a Claim Distinct from Breach of Fiduciary Duty}

The appraisal hearing is by its very nature distinct from a hearing over allegations of a breach of fiduciary duty. Where the statute confers the right to an appraisal following a merger, that right exists regardless of whether the merger is the product of breach of fiduciary duty. Appraisal is therefore generally understood as entirely a valuation exercise, in which evidence of breach of fiduciary duty is irrelevant. ${ }^{41}$ It is true, of course, that many appraisal claims proceed concurrently-and sometimes in a consolidated proceeding - with allegations of breach of fiduciary duty. This is a judicially economical approach, where the appraisal analysis would overlap with the determination of fair value as part of entire fairness scrutiny. ${ }^{42}$ Yet a claim that the merger violates the

40. See supra note 31 and accompanying text.

41. Glassman v. Unocal Exploration Corp., 777 A.2d 242, 248 (Del. 2001); Ala. By-Products Corp. v. Neal, 588 A.2d 255, 257 (Del. 1991) (acknowledging the pertinence of unfair dealing in assessing credibility, but reiterating that “claims for unfair dealing cannot be litigated in a statutory appraisal proceeding”).

42. The practice of concurrently addressing appraisal and fiduciary duty claims was first explicitly endorsed by the Delaware Supreme Court in the first of its several opinions in the Technicolor litigation. Cede \& Co. v. Technicolor, Inc., 542 A.2d 1182, 1191 (Del. 1988). Since that time, numerous cases have had valuation and fiduciary duty issues tried together. See, e.g., In re Emerging Commc'ns, Inc. S'holders Litig., Civ. A. No. 16415, 2004 WL 1305745, at*1 (Del. Ch. May 3, 2004); ONTI, Inc. v. Integra Bank, 751 A.2d 904 (Del. Ch. 1999); In re Radiology Assocs., Inc., 611 A.2d 485, 488 (Del. Ch. 1991). In other cases, appraisal 
directors' or controlling shareholder's fiduciary duty remains foreign to the pure valuation exercise contemplated by the appraisal statute.

Nevertheless, we claim that concepts related to the fiduciary duty of loyaltyparticularly the expression of that duty in the doctrine of corporate opportunity-may help resolve the issue framed in the preceding section, namely the characterization of the nature of the enterprise being valued. The prototypical corporate opportunity case involves allegations that a director or executive took for her personal use and profit a corporate opportunity that should have been offered to the corporation. ${ }^{43}$ This often involves the use of corporate property, but that is not a necessary part of the complaint. ${ }^{44}$ Typically, the taking of the opportunity has already occurred and the case is about whether that opportunity was one that should have been considered as belonging to the corporation itself.

What "belongs" or "will belong” to the corporation, however, is also at the heart of the question of the nature of the enterprise being valued. The cases in which we are interested involve a corporate opportunity that has not yet been taken, but that will be taken after the minority shareholders have been squeezed out. In almost all of these cases the use of the corporation's property is central to the transaction. Specifically, the assets of the corporation will be managed differently after the squeeze-out in a manner that is value creating. If such value enhancing transactions should be considered to be part of the nature of the enterprise being appraised, a concept of value allocation similar to the corporate opportunity doctrine could usefully be employed in assessing which such transactions should be considered to be part of the nature of the enterprise. ${ }^{45}$

\section{Types of Mergers Where the Appraisal Remedy is Available}

As we explain below, the task of defining "fair value" in appraisal proceedings is and should be informed by understanding the situations in which the appraisal remedy is available. The statute confers appraisal rights in only three types of situations, cases involving closely held corporations, where no market value is available; cash-out mergers; and short-form mergers regardless of the consideration. ${ }^{46}$ In practice, this reduces to two situations - the case of the cash squeeze-out merger and the merger involving a close corporation, and most of these are squeeze-out mergers as well.

proceedings have proceeded independently of fiduciary duty actions. See, e.g., Prescott Group Small Cap, L.P. v. Coleman Co., Inc., Civ. A. No. 17802, 2004 WL 2059515 (Del. Ch. Sept. 8, 2004); In re Coleman Co. S’holders Litig., 750 A.2d 1202 (Del. Ch. 1999).

43. See, e.g., Telxon Corp. v. Meyerson, 802 A.2d 257, 259 (Del. 2002); Broz v. Cellular Info. Sys., Inc., 673 A.2d 148, 154 (Del. 1996).

44. See, e.g., Guth v. Loft, Inc., 5 A.2d 503, 511 (Del. 1939).

If there is presented to a corporate officer or director a business opportunity which the corporation is financially able to undertake, is, from its nature, in the line of the corporation's business and is of practical advantage to it, is one in which the corporation has an interest or a reasonable expectancy, and by embracing the opportunity, the self-interest of the officer or director will be brought into conflict with that of the corporation, the law will not permit him to seize the opportunity for himself.

Id.

45. See infra Part IV.D.

46. Del. Code AnN. tit. 8, § 262(b) (2004). 
Consider first the case of the squeeze-out of minority shareholders by a controlling shareholder. If the company's stock is publicly and actively traded, the evidence on financial market efficiency suggests that the share value will reflect the current earning power of the company's assets and investors' views as to the competency of management in achieving the value of the corporation. If the managers are managing the company to maximize the value of the corporation, the market will so perceive, and the share price will be a good measure of the value of the company. Suppose, however, that the market believes that the insider controllers are managing the assets badly or are managing in their own interest rather than in the interest of the other shareholders. In this case, the efficient financial market would correctly discount the market price below any reasonable measure of what the law might deem "fair" value. If the dissenting stockholders were cashed out at the depressed market value, the controlling shareholder would have succeeded in enriching itself by underpaying the minority for their shares. ${ }^{47}$

The problem is exacerbated precisely when there is a controlling shareholder because the company is not subject to the market for corporate control, which provides one of the major barriers to directors taking excessive private benefits. The result is that minority shares can remain indefinitely below their true or "fair" value, since claims of managerial breach of fiduciary duty are by no means a thoroughly effective and cost-free check. The amount of private benefits that are subtracted off the value of the firm by the market gives rise to the observation that the more faithless the controller as fiduciary, the less it would have to pay to the minority shareholders in appraisal.

Appraisal is also available in a short-form merger, regardless of the consideration used in the squeeze-out. The case of the short-form merger generates the same problem as the first, but with the added burden that appraisal is the exclusive remedy, except in cases involving fraud or the like. ${ }^{48}$ At least in the former case, the majority shareholder has a fiduciary duty to pay a fair price, and a low-ball unfair merger price does not meet this obligation. In the case of a short-form merger, however, an entirely unfair low-ball price in itself gives rise to no fiduciary duty-based remedy. Moreover, if the company's shares still publicly trade, the market price is even less likely to be an accurate measure of fundamental value than in the prior case.

The final area where appraisal is used is where the firm being appraised is a close corporation. The unique problem here is that there are no market-based prices to provide a guide to valuation. Moreover, the valuation principles that have been adopted by the courts—DCF plus a version of the capital asset pricing model—work best in the case of public companies. The public companies have SEC filing requirements that meet a high standard of reporting. In addition, the capital asset pricing model was devised to estimate the appropriate discount rate for publicly traded companies, not private ones. ${ }^{49}$ Consequently, even faithful fiduciaries who take little in the way of private benefits and who may believe in good faith that they are offering a fair price are in fact offering inadequate consideration. Valuation principles cannot offer more than a range of fair values. Hence, there has to be an appraisal-type remedy-even with the best acting controllers-because controllers are given discretion in setting the merger price.

\footnotetext{
47. See infra Part III.B.1.

48. Glassman v. Unocal Exploration Co., 777 A.2d 242 (Del. 2002).

49. For an explanation of the capital asset pricing model, see supra note 33 .
} 
In light of where the appraisal remedy is available, the transactions giving rise to that remedy are ones approved and adopted by controlling shareholders. And for reasons to be discussed, ${ }^{50}$ it is significant that such controlling shareholders are frequently, if not predominantly, nondiversified individuals, families, or closely held enterprises. ${ }^{51}$

\section{APPRAisAl THEORY, AgenCy COSTS, AND A THREe-PART \\ CATEGORIZATION OF THE CASES}

\section{A. Appraisal Theory: Problem to be Solved and Alternative Concepts of Fair Value}

What is the problem that appraisal seeks to resolve and how does the resolution accommodate the courts' preference for going concern value as the core concept of "fair value"? The traditional answer supplied by the courts is that appraisal was a statutory trade that took away from individual shareholders the right to veto a merger. ${ }^{52}$ Since a merger agreed upon by two boards of directors acting at arm's-length is presumptively value enhancing, the statutory trade removed a possible source of oppression by the minority - it deprived minority shareholders of the ability to hold out for non-pro rata benefits in order to sell their veto power to the majority.

Much has changed, however, since the hypothesized statutory bargain was originally struck. Today, the current appraisal remedy is limited in reach, applying to situations where minority shareholders may be particularly vulnerable. ${ }^{53}$ The vulnerability does not arise, however, if the minority and majority merely disagree over whether a proposed merger is actually in the best interests of the corporation and its shareholders. Instead, the

50. See infra Part III.A.

51. See, e.g., Gonsalves v. Straight Arrow Publishers, Inc., 701 A.2d 357 (Del. 1997) (merger effected by controlling shareholder Jann Wenner, founder of Rolling Stone magazine); Finkelstein v. Liberty Digital, Inc., Civ. A. No. 19598, 2005 WL 1074364 (Del. Ch. Apr. 25, 2005); Cede \& Co. v. MedPointe Healthcare, Inc., Civ. A. No. 19354-NC, 2004 WL 2093967 (Del. Ch. Aug. 16, 2004); Lane v. Cancer Treatment Ctrs. of Am., Inc., Civ. A. No. 12207-NC, 2004 WL 1752847 (Del. Ch. July 30, 2004); Ng v. Heng Sang Realty Corp., Civ. A. No. 18462, 2004 WL 1151980 (Del. Ch. Apr. 22, 2004); Borruso v. Commc'ns TeleSystems Int'l, 753 A.2d 451 (Del. Ch. 1999); Ryan v. Tad's Enters., Inc., 709 A.2d 682 (Del. Ch. 1996), aff'd, 693 A.2d 1082 (Del. 1997); Kleinwort Benson Ltd. v. Silgan Corp., Civ. A. No. 11107, 1995 WL 376911 (Del. Ch. June 15, 1995); Hodas v. Spectrum Tech., Inc., Civ. A. No. 11265, 1992 WL 364682 (Del. Ch. Dec. 7, 1992); In re Radiology Assocs., Inc., 611 A.2d 485 (Del. Ch. 1991).

52. See, e.g., Applebaum v. Avaya, Inc., 812 A.2d 880, 893 (Del. 2002); Ala. By-Products Corp. v. Cede \& Co., 657 A.2d 254, 258 (Del. 1995). The historical accuracy of this trade-off story is questionable, however, given the fact that the appraisal remedy was often added well after the adoption of statutes permitting mergers without unanimous consent. See Robert B. Thompson, Exit, Liquidity, and Majority Rule: Appraisal's Role in Corporate Law, 84 GEO. L.J. 1, 14 (1995).

Appraisal statutes are often presented as having been enacted in tandem with statutes authorizing consolidation or merger by less than unanimous vote, but there was a significant difference in the spread of the two statutes. By the turn of the century, a dozen states had statutes authorizing consolidations for corporations generally, but only five of those states had appraisal statutes.

Id. On the other hand, even if the trade story did not happen in precisely the manner traditionally suggested, the function of the merger statutes and the appraisal remedy to eliminate minority hold-up of value creating transactions remains significant.

53. Randall S. Thomas, Revising the Delaware Appraisal Statute, 3 DEL. L. REV. 1, 16-17 (2000); Thompson, supra note 52, at 23. 
vulnerability applies to a more limited range of mergers: specifically, squeeze-out and close corporation mergers in which the potential effect of the merger is to enrich the majority shareholder at the expense of the minority shareholders.

As structured, the effect of the remedy is to require that squeeze-out or close corporation mergers are transactions that can satisfy a Pareto superior test, under which the dissenting shareholders are not made worse off. ${ }^{54}$ Assuming this is the intent, how can it be accomplished? The answer is to pay the dissenting shareholders the cash equivalent of the present value of the future benefits that shareholders could have expected to receive if they had continued to hold their shares.

Applying this formulation is not a trivial task, however, and even with its limited reach, the appraisal remedy requires a carefully accomplished legal balancing act. Both parties have an interest in a legal rule that encourages some individuals or entities to become controllers while protecting the interests of the minority shareholders. This means that controllers can continue to exercise the rights of control, which, in the context of the appraisal and merger statutes, means allowing them to engage in squeeze-out mergers or mergers involving close corporations. But it also means protecting minority shareholders so they are willing to invest in companies with controllers. In cash-out mergers, the rule must insure that the minority shareholders are not made worse off by the transaction.

But minority shareholders also need the controlling shareholders, and would be worse off if the legal rules made it unprofitable for controlling shareholders to serve in that capacity. The controlling shareholders of the world are non-diversified shareholders who take on unsystematic company risk by being incompletely diversified. ${ }^{55}$ They do so in return for the benefits of exercising control. The obvious benefit of having controlling shareholders is that agency costs are reduced because the interests of the controller are more aligned with the corporation. Minority shares can represent a very profitable investment for shareholders who essentially ride the coattails of the nondiversified, and hence focused, controlling shareholder. With the correct balance achieved, the controlling shareholder can exercise its rights of control, restricted only by a constraint that it pay fair value or, in other words, that its actions not make the minority shareholders worse off.

In order to define that constraint, and to assure that the controller does not make the minority shareholders worse off by means of a squeeze-out, we next need to determine the main vulnerabilities of the minority shareholders in such a situation. The principal concerns of the minority shareholder center on the motive of the controller and the timing of the transaction. Why implement the squeeze-out now? Is some good news about to occur that would change the value of the company? If this were the case, then the law needs to be particularly vigilant that the potential for opportunism by the controller be checked. To what extent is the case law sensitive to this situation when it determines the "fair value" to be received by the minority shareholders? On the other hand, there are lots of other reasons for squeeze-outs that have nothing to do with a forthcoming upward valuation of the assets. Does the case law adequately protect the minority shareholders in

54. See, e.g., Frank H. EASTERBrook \& DANiEL R. Fischel, The ECONOMiC Structure of CORPORATE LAW 139 (1991) (stating that appraisals "require that shareholders receive the equivalent of what they give up but do not require sharing of the gain from the change in control”).

55. See supra note 51. 
the former situation, while not over-compensating the minority in the latter situation?

\section{B. Three Alternative Measures of Fair Value}

Achieving the desired balance through an appropriate measure of fair value has been relatively easy, at a conceptual level. For decades, the Delaware case law has adhered to going concern value as the correct concept for interpreting fair value. ${ }^{56}$ That concept essentially promises that dissenting shareholders are to receive the value of what was being taken from them or, alternatively stated, the value of the benefits they would receive if they held the shares indefinitely. ${ }^{57}$ The breadth and ambiguity of that general standard, however, has required the courts to consider the three principal approaches to valuation that we discuss below: namely, market value; third-party sale value; and going concern value as measured by the present value of future free cash flows.

\section{Market Value}

The advocate of a market value standard for determining fair value asks: if financial markets are efficient, why not simply use the market value of the shares as the best available measure of fair value? ${ }^{58}$

For the reasons noted above, using the market price to measure the value of the firm is simply not viable for the types of cases to which the appraisal remedy applies. As noted, the financial markets will price the firm based on the plans of the controller. If the market believes that the controller will under-manage the firm, the price will fall to reflect this fact. Critically, the controller is not deterred from doing so since the market for corporate control is absent. If the shares' current market price were used to value the firm, the controller would be encouraged to under-manage, since the more it did so, the less it would have to pay for the minority interest in a squeeze-out merger.

Clearly, market price is also not a candidate in one of the other cases where

56. The term "going concern value" is standard parlance in the Delaware case law describing the valuation standard to be applied in statutory appraisal proceedings. For just a few of the recent instances in which the courts used that terminology, see Gholl v. eMachines, Inc., Civ. A. No. 19444-NC, 2004 WL 2847865, at *4 (Del. Ch. Nov. 24, 2004), aff'd, 875 A.2d 632 (Del. 2005); Dobler v. Montgomery Cellular Holding Co., Civ. A. No. 19211, 2004 WL 2271592, at*9 (Del. Ch. Sept. 30, 2004); Prescott Group Small Cap, L.P. v. Coleman Co., Civ. A. No. 17802, 2004 WL 2059515, at *25 (Del. Ch. Sept. 8, 2004); Lane, 2004 WL 1752847, at *15; Doft \& Co. v. Travelocity.com Inc., Civ. A. No. 19734, 2004 WL 1366994, at *1 (Del. Ch. June 10, 2004); Heng Sang Realty Corp., 2004 WL 1151980, at *4; Cede \& Co. v. Technicolor, Inc., Civ. A. No. 7129,2003 WL 23700218, at *1 (Del. Ch. Dec. 31, 2003), aff'd in part, rev'd in part, 875 A.2d 602 (Del. 2005); Taylor v. Am. Specialty Retailing Group, Inc., Civ. A. No. 19239, 2003 WL 21753752, at *2 (Del. Ch. July 25, 2003).

57. See, e.g., Cede \& Co. v. Technicolor, Inc., 684 A.2d 289, 298 (Del. 1996); see also Cavalier Oil Corp. v. Harnett, 564 A.2d 1137, 1145 (Del. 1989).

The underlying assumption in an appraisal valuation is that the dissenting shareholders would be willing to maintain their investment position had the merger not occurred. Accordingly, the Court of Chancery's task in an appraisal proceeding is to value what has been taken from the shareholder, i.e., the proportionate interest in the going concern.

Id. at 1144 (citing Tri-Cont'l Corp. v. Battye, 74 A.2d 71, 72 (Del. 1950)).

58. BREALEY ET AL., supra note 31, at 332 (making the point that all assets in efficient markets sell for the value of their discounted free cash flow); Lucian A. Bebchuk \& Marcel Kahan, Adverse Selection and Gains to Controllers in Freezeouts, in CONCENTRATED CORPORATE OWNERSHIP 247, 250 (Randall K. Morck ed., 2000); Benjamin Hermalin \& Alan Schwartz, Buyouts in Large Companies, 25 J. LEG. STUD. 351, 370 (1996). 
appraisal regularly occurs- the close corporation. In this case there is no publicly traded market price and there is no check on whether any non-public market transactions sales that occur are an accurate indicator of value. In summary, using the public market price as the measuring stick for fair value provides inadequate protection for the minority and allows for a potential windfall for the controller. ${ }^{59}$

The law's rejection of public market prices should not be viewed as a wholesale rejection of efficient market theory. ${ }^{60}$ Quite to the contrary, public market prices are used in the appraisal remedy to justify the market-out exception, a significant limitation on the scope of the remedy. ${ }^{61}$ In cases where stock rather than cash is the consideration, dissenting shareholders cannot ask for an appraisal of their shares. The usual argument is that the market does a more efficient job than the courts in measuring going concern value. ${ }^{62}$

The market-out exception is, however, roundly criticized for lacking a coherent scope, being over-inclusive in some cases and under-inclusive in others. ${ }^{63}$ This criticism of the market-out exception is one we agree with. However, it is not a major problem, best as we can tell, because of the nature of the deals that might involve appraisal and the manner in which the courts handle these deals.

In third-party initiated mergers between public companies, the market will do as good a job in pricing a cash deal as a stock deal. Yet the law provides for appraisal in cash deals, but not in stock deals. What matters is not the consideration, but rather whether the company is publicly traded or whether there is a controlling shareholder. In third-party deals, appraisal is probably not required in either stock or cash deals and hence the law is over-inclusive with respect to these transactions. ${ }^{64}$ However, no problem is created because the appraisal court correctly handles these cases, as we shall see below. 65

In a reorganization forced by a controlling shareholder, the minority can be equally disadvantaged whether given stock (for example, nonvoting stock) or cash. In the case of

59. Bebchuk \& Kahan, supra note 58, at 250.

The very power of a controlling shareholder to freeze out the minority shares-and to set the freezeout price equal to the prefreezeout market price-will depress the prefreezeout market price of the minority shares. As a result, the prefreezeout market price of minority shares will be substantially below the expected "intrinsic" value of the minority shares absent a freezeout.

Id.

60. It must be acknowledged, of course, that Delaware valuation case law has always had a strong streak of distrust of public market share prices as a dispositive measure of fair value. See, e.g., Smith v. Van Gorkom, 488 A.2d 858, 875-76 (Del. 1985); Chicago Corp. v. Munds, 172 A. 452, 456 (Del. Ch. 1934).

61. S. SAMuel ARsht \& LeWIS S. Black, JR., The 1973 Amendments to the Delaware CORPORATION LAW 372 (1973) ("The theory behind this denial of appraisal rights is that the stockholders have a 'market out' if they consider the terms of the merger unfair or inadequate since their shares are sufficiently widely held to permit ready sale.”).

62. See, e.g., MODEL BUS. CORP. ACT $\S 13.02 \mathrm{cmt}$. 2 (2005) (The market out provision "is predicated on the theory that where an efficient market exists, the market price will be an adequate proxy for the fair value of the corporation's shares, thus making appraisal unnecessary.”).

63. See, e.g., Thomas, supra note 53, at 20-21.

64. For a case suggesting that appraisal may be a backstop against deficiencies in the sale process, however, see Gholl v. eMachines, Inc., Civ. A. No. 19444-NC, 2004 WL 2847865 (Del. Ch. Nov. 24, 2004).

65. See infra Part IV.A.1 (discussing Union Ill. 1995 Inv. Ltd. P’ship v. Union Fin. Group, Ltd., 847 A.2d 340 (Del. Ch. 2003)). 
stock, the minority is mistreated by getting too few shares, and in a cash deal the minority can be equally mistreated by getting too few dollars. Hence, in this case the law is arguably under-inclusive. But here again the lack of perfection is not a major problem because of the nature of the deals. In such cases the controller rarely wants to leave the minority shareholders in place, so these deals are consummated with cash as the consideration and hence appraisal is triggered. ${ }^{66}$ In particular, where the controller is engaging in unjust enrichment of some type, leaving the minority in place will only leave a group in place that will have standing to bring suit. ${ }^{67}$

\section{Third-Party Sale Value}

The second candidate for valuing companies in appraisal is to use third-party sale value. ${ }^{68}$ This is a more viable candidate than the market price: one deceptively attractive reason to favor third-party sale value is that it seems to accord with the traditional economics definition of value. In standard economics, an asset's value is determined by its next best use, or what is referred to as its opportunity cost. ${ }^{69}$ The economist is interested in the cost to society of an asset. The cost to society is what is foregone by having the asset's resources tied up in that fashion, rather than being applied in its next best use. The value associated with the next best use is the best measure of the cost to society. ${ }^{70}$

But this opportunity cost definitional construct has no particular claim to serve as the preferred measurement of fair value. The financial economist recognizes that the "current use value" is a better measure of the value produced by the asset and thus a better measure of going concern value. Opportunity cost, on the other hand, does not measure the value of what the petitioner has given up in the squeeze-out.

Moreover, and counter to the intuition that third-party sale value would provide greater protection to minority shareholders, opportunity cost as a theoretical concept actually results in a lower value. In equilibrium, all value-enhancing transactions have already taken place, so that the value to the next best user is actually lower than current use value. This is very different from the idea that there are lurking buyers around ready to buy the asset for more than the value to the current owners. In fact, most of the time, the great majority of firms are not "up for sale” and there is good reason to assume that if

66. Of the 30 Delaware appraisal cases since 1983 that did not involve a second-step merger as part of a third-party acquisition, only two involved a merger in which the merger consideration prescribed by the controlling shareholder was common stock of the controlling shareholder or the surviving corporation. Finkelstein v. Liberty Digital, Inc., Civ. A. No. 19598, 2005 WL 1074364 (Del. Ch. Apr. 25, 2005); Hintmann v. Fred Weber, Inc., Civ. A. No. 12839, 1998 WL 83052 (Del. Ch. Feb. 17, 1998).

67. See, e.g., Lewis v. Ward, 852 A.2d 896, 900-01 (Del. 2004).

68. See, e.g., In re Valuation of Common Stock of McLoon Oil Co., 565 A.2d 997, 1004 (Me. 1989).

The valuation focus under the appraisal statute is not the stock as a commodity, but rather the stock only as it represents a proportionate part of the enterprise as a whole. The question for the court becomes simple and direct: What is the best price a single buyer could reasonably be expected to pay for the firm as an entirety? The court then prorates that value for the whole firm equally among all shares of its common stock.

Id.

69. BREALEY ET AL., supra note 31, at 16.

70. Id. 
all these firms were put up for sale, at least some would fetch less than going concern value. We return to this point below.

The advocates of third-party sale value, however, do have a point. Since the controller can choose the timing of the squeeze-out or close-corporation merger, there is at least a concern that the timing puts the minority shareholder at a disadvantage. The debate here has similarities to the debate over a related legal rule-the rule that allows controllers to sell their own shares (without selling or merging the corporation) without providing an equal opportunity to minority shareholders to sell their shares. ${ }^{71}$ The remedy for those concerned about minority oppression in that case is to impose an equal opportunity rule. ${ }^{72}$ By allowing the minority to sell at the same price as the controller, the possibility that the controller is acting opportunistically is neutralized.

However, with respect to freeze-outs and close corporation mergers, there is no comparable equal opportunity rule. By its very nature, the transaction is designed to treat the majority and minority shareholders differently. The only way to prevent the minority from being treated differently, and thus preserve equal opportunity, would be to restrict the right of controllers to accomplish freeze-out mergers, which to our knowledge no one recommends.

Rather than essentially prohibit squeeze-out mergers, the alternative remedy favored to protect minority shareholders is to define fair value as third-party sale value. If one assumes that the controller is or may be "up to no good" in timing the squeeze-out, then third-party sale value will be higher than going concern value. While the rule would likely lead to an over-compensation of minority shareholders, it would also provide a valuation cushion to protect the minority from an under-valuation imposed by the timing. But, again, like the equal opportunity rule it has the weakness of preventing mergers that enhance value.

What further renders a third-party sale value rule unattractive is that it violates the basic premise of the statutory remedy. The directors get to approve a merger transaction they believe is in the best interest of the corporation, but in so doing the minority has a remedy that provides them with the value of that which is being taken from them. Thirdparty sale value may have the promise of providing greater value to minority shareholders, but if one truly adopts that valuation metric, there is no guarantee of that result. Third-party sale value might be higher, but it also might be lower than going concern value.

In addition, third-party sale value as a legal rule would also turn on its head the relationship between the controller and the minority shareholders. The controller, in order to go ahead with the planned transaction, would need to prove to the court that the

71. See, e.g., Hollinger Int’l, Inc. v. Black, 844 A.2d 1022, 1087 (Del. Ch. 2004) (“[M]inority stockholders . . . have no common or statutory right to tag-along in a transfer of control at the parent level.”); Mendel v. Carroll, 651 A.2d 297, 305 (Del. Ch. 1994) (“The law has acknowledged, albeit in a guarded and complex way, the legitimacy of the acceptance by controlling shareholders of a control premium.”); Zetlin v. Hanson Holdings, Inc., 397 N.E.2d 387, 388 (N.Y. 1979) (“[A]bsent looting of corporate assets, conversion of a corporate opportunity, fraud or other acts of bad faith, a controlling stockholder is free to sell, and a purchaser is free to buy, that controlling interest at a premium price.”). See generally Gilson \& Gordon, supra note 10, at 793-94.

72. William D. Andrews, The Stockholder's Right to Equal Opportunity in the Sale of Shares, 78 HARV. L. REV. 505, 512 (1965). 
consideration being offered equals the "Revlon price," that is, the top price that would be paid in any reasonably available third-party transaction. This would impose a rule that would have outcome similarities to Revlon duties, ${ }^{73}$ but in this case it would be the legal rule that forced the controller to seek a third-party price, or at least to pay the minority shareholders the "Revlon price." As the case law establishes, however, no such legal rule exists. ${ }^{74}$ Imposing a third-party sale rule would undercut this basic right of control, presumably making acquisition and ownership of control a much less attractive option given the non-diversification risks that it involves. Such a rule would also discourage controlling shareholders from buying out minority shares, given the availability of alternatives to the costs of public share ownership, such as deregistration and delisting, sometimes described as "going dark."75

There are further problems associated with equating fair value to the "Revlon price." The basic measurement problem of determining the "Revlon price" is that no such number may be available. In the case of the equal opportunity rule, the third-party offering price to the controller is a known fact. The court does not need to estimate its value. The only question is whether the transaction will still take place if the third-party has to offer the same price to all shareholders.

Having the court determine third-party sale value when no such offer has been made, on the other hand, imposes additional risk on the transaction as a result of both measurement difficulties as well as a core conceptual issue as to whether a higher thirdparty sale price could actually exist. Since no third party has made an offer in most of the cases, the court would need to construct a market of third-party potential buyers and then determine an offering price. This third-party sale valuation exercise is subject to significant error and thus introduces a substantial new risk into the process. This risk would add a further negative element in the calculus as to whether an otherwise valueenhancing merger should take place.

It also should be recognized that a third-party sale value rule imposes additional risk on the minority shareholders as well. As noted above, advocates of third-party sale value assume that all assets have greater value than their current use. This cannot be true as a general proposition. Firms like Microsoft, Berkshire Hathaway, eBay, and many others are probably very efficiently run and arguably no third party could do better. Taken seriously, imposing a third-party sale value means that the minority takes on the risk of being paid less than going concern value.

Therefore, if the third-party sale value rule were in effect, the result would be to create a new potential for controller opportunism. The current concern is that the controller will use the squeeze-out when the going concern value is low and about to increase. Under a third-party sale value rule the concern would be the converse, namely

73. Revlon, Inc. v. MacAndrews \& Forbes Holdings, Inc., 506 A.2d 173, 182 (Del. 1986).

74. See, e.g., McMullin v. Beran, 765 A.2d 910, 919-20 (Del. 2000); Bershad v. Curtiss-Wright Corp., 535 A.2d 840, 845 (Del. 1987); Orman v. Cullman, Civ. A. No. 18039, 2004 WL 2348395, at *22 (Del. Ch. Oct. 20, 2004); Peter Schoenfeld Asset Mgmt. LLC v. Shaw, Civ. A. No. 20087-NC, 2003 WL 21649926, at *2 (Del. Ch. July 10, 2003), aff'd, No. 384,2003, 2003 WL 22998806 (Del. Dec. 17, 2003).

75. See, e.g., Going Dark in the Sarbanes-Oxley Era, SEC. InDUSTRY NEWS, Dec. 20, 2004, at 5; Claudia H. Deutch, The Higher Price of Staying Public, N.Y. TiMEs, Jan. 23, 2005; Christian Leuz et al., Why Do Firms Go Dark? Causes and Economic Consequences of Voluntary SEC Deregistrations (Nov. 2004) (unpublished paper, presented at the Am. Fin. Ass’n 2006 Meetings), available at http://ssrn.com/abstract=592421. 
that the controller would time the squeeze-out to occur when third-party sale value is arguably lower than going concern value.

As we will discuss below, on the other hand, there are times when elements of thirdparty sale value may indeed be evidence that could be used in an appraisal proceeding.

\section{Going Concern Value}

The third possible measure of fair value, and the one adopted by the courts, is going concern value, and a direct measure of that concept wherever possible. The concept of going concern value posits that a shareholder should receive the value of what is taken in the merger, namely the returns on the holder's shares that would have been generated had the merger not occurred and the holder continued to hold those shares. ${ }^{76} \mathrm{~A}$ direct measure of going concern value is entirely consistent with the way modern finance calculates the value of the asset or a company. Although the term "intrinsic value,"77 a favorite of the court, is not used in finance, a close cousin, fundamental value, is used. ${ }^{78}$ The value of an asset is measured by the benefits it provides to the owner. For stock in a corporation, the benefits are the discounted stream of dividends plus the appreciation in the value of the stock, that is, the DCF value mentioned above. Alternatively, but giving the same answer, the value can be measured as the discounted value of the free cash flows generated by the company's assets. ${ }^{79}$

The DCF analysis is a forward looking concept, dependent on the future value of the free cash flows. The future free cash flows can be divided into two components. The first component is the free cash flows generated by the assets already owned by the firm. Although the future cash flows can vary with the business cycle and industry conditions, the current asset base of the company is known, and there are various methods of determining the value of the free cash flows that it will generate that are consistent with DCF analysis. ${ }^{80}$

The term going concern, as developed and applied by the courts, is, on reflection, unduly limited in relation to properly understood DCF analysis. The term "going concern" conjures up a picture of a firm with a fixed capital stock that is owned by the firm and is fully known at the time of the valuation exercise. Although this may have led some to focus unduly on this first component of the analysis-returns generated by assets already owned by the firm - the currently owned capital is only the first of two components.

Typically a company that is generating free cash flow does not pay it all out in dividends, but instead reinvests at least some of the money. ${ }^{81}$ Consequently, the present

76. See, e.g., Paskill Corp. v. Alcoma Corp., 747 A.2d 549, 553 (Del. 2000) (“The underlying assumption in an appraisal valuation is that the dissenting shareholders would be willing to maintain their investment position had the merger not occurred.”).

77. See, e.g., id. (citing Tri-Cont'l Corp. v. Battye, 74 A.2d 71 (Del. 1950)); Chicago Corp. v. Munds, 172 A. 452, 456 (Del. Ch. 1934).

78. Michael L. Wachter, Takeover Defense When Financial Markets Are (Only) Relatively Efficient, 151 U. PA. L. REV. 787, 798 (2003) ("[T]he corporation's fundamental value is the sum of the free cash flows generated by the company's assets.”).

79. See supra note 31 and accompanying text.

80. BREALEY ET AL., supra note 31, at 72.

81. Id. at 415 . 
value of the firm is not only the free cash flows from the existing assets, but also the free cash flows that will be earned on the new investments. The return on the reinvestment of the firm's free cash flow is the second component of the analysis. This second element can easily be as large as or larger than the first, but in any case it cannot be ignored. In finance textbook terminology, this second element is the present value of the firm's growth opportunities. ${ }^{82}$ In total then, the firm can be divided into the present value of a level stream of earnings based on the current assets and the present value of the growth opportunities generated by reinvestment opportunities.

This breakdown of value into the two components is different from and should not be confused with the other two-part division found in many appraisal cases. In the latter two-part division there is an initial period where annual forecasts are available on the key parameters and a terminal value where one resorts to an estimate about future growth and discount rates applicable in the future. ${ }^{83}$ The reinvestment opportunity component in our categorization can begin to occur next year and will continue into the future. It is not an overlapping concept with terminal value. Indeed, as we shall see below in our analysis of appraisal cases, the critical reinvestment opportunities are likely to have a significant effect on value by affecting the cash flows during the period when annual forecasts of the key parameters are available. ${ }^{84}$

The upshot is that in valuing the firm, one is not only valuing the current asset stock and the return on those assets; the value of the firm also includes the reinvestment in new assets and the return on those new assets. Corporate reinvestment opportunities are thus an ongoing business matter that is regularly occurring as the firm considers how to reinvest its free cash flows.

As we shall see, it is these reinvestment opportunities that are at the heart of the most difficult appraisal cases. The problem occurs when the controller squeezes out the minority shareholders in anticipation of taking advantage of the new reinvestment opportunities available to the firm. Although the court has grappled unevenly with whether these values should be included in the analysis, the finance perspective would say that they should be included as long as they are known to the controller and are part of the corporate policy of the existing firm before the merger. Since the finance models do not distinguish between explicit and implicit or even hidden corporate plans, the valuation exercise should include the firm's reinvestment opportunities that are known to the controller whether or not they are disclosed to anyone else at that time. Consequently, the correct calculation of the value of the firm includes the discounted free cash flows from these opportunities. ${ }^{85}$

The law should, and usually does, give the same answer. If the minority shareholders were not being squeezed out, they would continue to hold the stock into the future. What they lose in the squeeze-out is thus the discounted value of the free cash flows of both the original assets and the return on the reinvestment opportunities. These shareholders then can be made no worse off, as long as they are paid their proportional share of that discounted value. In short, the shareholders are paid the value of what has

82. Id. at 73 .

83. See, e.g., Cede \& Co. v. JRC Acquisition Corp., Civ. A. No. 18648-NC, 2004 WL 286963, at *4-5 (Del. Ch. Feb. 10, 2004).

84. BREALEY ET AL., supra note 31, at 71.

85. Id. at 508 . 
been taken from them.

From a welfare perspective, the going concern value rule provides the minority shareholders with the value of what was taken from them, and therefore, makes the transaction Pareto-superior. This requires that the going concern value be correctly measured. Although this is a difficult task, it is manageable. A third-party sale value rule is arguably intended to make the minority shareholders better off than if the controller had not initiated the transaction, by providing the minority shareholders with a higher value based on what a third party would offer. As noted earlier, however, the third-party sale value rule introduces a gamble into the process because the minority shareholders will be paid a construct that the court must estimate. This is not only a difficult task, but may not be manageable, and is in any event inconsistent with the right conferred upon the controlling shareholder to refrain from selling control to a third party. Moreover, as we show in the discussion of the cases, ${ }^{86}$ we believe that our inclusion of reinvestment opportunities resolves many of the troubling cases that lead commentators to favor thirdparty sale value.

\section{Agency Costs}

Before proceeding to our delineation of the categories of appraisal situations and the appropriate valuation standards, one more foundational question needs to be explored: namely, how do agency costs affect the valuation calculation? Agency costs are those costs that arise because of the separation of management and control and the resulting imperfect alignment of the interest of the shareholders and the directors.

Agency costs are sometimes viewed as a market failure in the sense that if directors and managers could be policed without cost, agency costs would disappear. But this definition suffers from the obvious fact that policing directors and managers is not costless. ${ }^{87}$ In a sense, all costs could be defined away if we assumed a perfect world. Copper is costly because of the need to extract it. In a perfect world, extraction costs would be zero and producing copper in pure form would be as free as monitoring directors and managers. More closely analogous to agency costs are information costs. But information gathering is costly just as monitoring and bonding are costly. Devising legal rules based on unrealistic assumptions as to transaction costs is not useful.

This is not the place to get into a philosophical debate between real costs in a real economy and hypothetical and lower costs in a perfect economy without transaction costs. We note, however, that ever since the pathbreaking article of Jensen and Meckling, it has been assumed that agency costs are real costs and are borne by the controller when it sells shares publicly. ${ }^{88}$ First, what we refer to as agency costs are really the residual costs that continue after the economic actors and society determine the efficient level to spend on monitoring and bonding. Those residual agency costs reflect the nonalignment that continues after monitoring and bonding occur. Second, informed shareholders

86. See infra Part IV.C. (discussing the case law).

87. Indeed, important occupations in the American economy, from stock analysts to rating agencies, are based at least in part on the real need for principals to monitor agents and for agents to bond their behavior.

88. Michael C. Jensen \& William H. Meckling, Theory of the Firm: Managerial Behavior, Agency Costs and Ownership Structure, 3 J. FIN. ECON. 305 (1976) (stating that agency costs arise upon sale of equity to nonmanagers). 
understand that managers and directors sometimes act in their own interest rather than in the interest of the corporation, and shareholders will therefore pay less for firms' shares when they are sold to the public.

Since agency costs are, after all, real costs, they directly reduce the future free cash flow by reducing future revenue streams or increasing future costs. ${ }^{89}$ Consequently, the agency costs are built into the DCF analysis used to determine going concern value. In this sense, shareholders pay going concern value when they purchase shares.

For appraisal, the implications of principal-agent theory are clear. If, as predicted, shareholders buy shares at a price that is net of agency costs, then that discount should not be added back in when the firm is taken private. We believe that there is general agreement as to this point. If there is disagreement, it is over the effect of such a rule on efficiency; specifically, does it encourage managers and directors to increase agency costs? ${ }^{90}$ The answer to this question depends on understanding the implications of principal-agent theory. The remaining residual agency costs are an equilibrium result that depends on the legal system as well as the monitoring and bonding of the private actors. It is the legal rules that determine what behavior violates the fiduciary duty of managers and directors that determine the level of the remaining or residual agency costs. What constitutes faithless behavior by fiduciaries should be and is determined by fiduciary duty law, and the legal standards that result should be, and are, enforced. The appraisal remedy is not well designed to set the boundaries of fiduciary duties of controllers. ${ }^{91}$

This then directs us to a resolution of the efficiency implications of the appraisal rule. Behavior that reflects a violation of fiduciary duties should not be permitted to

89. For a detailed discussion of estimating the value of a company in the presence of agency costs, see Richard E. Kihlstrom \& Michael L. Wachter, Why Defer to Managers? A Strong-Form Efficiency Model (Univ. of Pa. Inst. for Law \& Econ., Research Paper No. 05-19, 2005), available at http://ssrn.com/abstract=803564. The agency problem means that revenue is lower than it otherwise would be (because managers and directors do not work as hard as they do in the perfect economy), costs are higher (because managers do not bargain as hard with suppliers), investments are made without the sharpest eye on profitability (because managers may want to manage larger firms), or for many other reasons. The result of these effects is that revenue is lower and costs are higher, and therefore, value is lower than it otherwise would be in a perfect economy where agency costs did not exist. In other words, these effects would result in a lower DCF value. But the amounts involved are unknown and probably unknowable. One reason that agency costs are unknowable is because there is no reason to presume that a controller who owns one hundred percent of the firm will maximize the value of the corporation. The one hundred percent controller can shirk, make fun investments that are not profitable, and do lots of other things that she may enjoy and cause her to maximize her utility (if not her profits). Since the controller bears all the costs of these adventures, we do not call this the same behavior when done by a controller of an agency cost.

90. We highlight that this is a hypothetical question since no one has an estimate of the costs involved.

91. In his article on control premiums, John Coates describes agency costs as arising from three sources: synergy value, expropriation value, and pure control value. Our discussion of synergy value is close to his. But Coates describes expropriation value as including not only fraud, theft, and breach of fiduciary duty, but also a gray area that includes costs that do not breach a fiduciary duty. Such costs hardly represent expropriation or even wrongdoing. While we would agree that expropriation costs, properly defined, should be added back into the value of the firm for appraisal purposes, the same is not true for these other costs. Coates also has another term that he calls "pure agency cost." The agency costs that do not breach a fiduciary duty are better viewed as pure agency costs, where we define the term to mean the residual agency costs that remain after the parties' monitoring and bonding costs are set at their efficient levels and society sets the appropriate enforcement of breach of fiduciary duty. John C. Coates, "Fair Value" as an Avoidable Rule of Corporate Law: Minority Discounts in Conflict Transactions, 147 U. PA. L. REV. 1251, 1274 (1999). 
lower the fair value that petitioners receive in appraisal. However, after going concern value is calculated as the discounted value of the free cash flows, no upward adjustment should be made to reflect an estimate of the entirely hypothetical level of residual agency costs that are assumed to remain in the system. ${ }^{92}$

\section{Three Prototypical Case Patterns}

With the foregoing background, we now find it useful to differentiate among three categories of transactions. In the first category, the current managers sell the company in an arm's-length transaction to a new controller who is taking the company private and thus squeezing out the shareholders. In the second, the current controller decides to take the company private and the evidence indicates that the controller has no intention to run the company any differently after the merger. Finally, in the third category, the current controller decides to take the company private and the evidence indicates that the controller will use the assets differently than the company has been using them. The third problem is clearly the most difficult to solve, but each raises interesting and important questions of appraisal.

\section{Category 1: Merger Involving a Third Party}

In this first category, the firm being appraised (Seller Co.) is being merged with Buyer Co., a third party entirely separate from Seller Co. and its controller. Buyer Co. is interested in buying the assets because of synergies, which means that when the assets of the two firms are combined they are worth more when managed together than when managed separately. In what way can the minority shareholders be disadvantaged in this case? What are our specific concerns? The short answer is that we are not much concerned as long as the deal is a true third-party transaction. ${ }^{93}$ This is an important caveat. In true arm's-length deals, the controller of Seller Co. has every incentive to sell the firm for the highest possible price. ${ }^{94}$

Assuming that Seller Co. bargains at arm's-length, it is likely that the synergies of

92. See Dobler v. Montgomery Cellular Holding Co., Civ. A. No. 19211, 2004 WL 2271592 (Del. Ch. Sept. 30, 2004).

Before using Sherman's DCF in the final computation, however, the court will remove the control premium. A DCF is a final valuation that does not need any additional correction, such as a control premium. Sherman had already corrected for Price's control of MCHC by modifying his inputs. Accordingly, the court will not include Sherman's additional control premium in its final valuation.

Id. at *17. The court also states that "Delaware courts generally do not apply control premia to DCF valuations.” Id. at *7 (citing Taylor v. Am. Specialty Retailing Group, Inc., Civ. A. No. 19239, 2003 WL 21753752, at *2 (Del. Ch. July 25, 2003)). See also SHANNON PRATT, THE LAWYER's BusinEsS VALUATION HANDBOOK 359 (2000) (“[DCF] value should represent the full value of the future cash flows of the business. Excluding synergies, a company cannot be worth a premium over the value of its future cash flows. Thus, it is improper and illogical to add a control premium to a DCF valuation.”).

93. See M.P.M. Enters., Inc. v. Gilbert, 731 A.2d 790, 796 (Del. 1999) ("Values derived in the open market through arm's-length negotiations offer better indicia of reliability than the interested party transactions that are often the subject of appraisals under $\S 262$. .").

94. See, e.g., Van de Walle v. Unimation, Inc., Civ. A. No. 7046, 1991 WL 29303, at *11 (Del. Ch. Mar. 7, 1991). 
the merger will be shared by the shareholders of the two companies. ${ }^{95}$ As a consequence of the synergies and the arm's-length deal, Seller Co.'s minority shareholders will actually receive what we usually refer to as third-party sale value. In effect, the minority receives more than going concern value. This result is likely to hold whether or not Seller Co. has a controlling shareholder or whether Buyer Co. has a controlling shareholder.

This first category accounts for relatively few actual appraisal cases. ${ }^{96}$ The reason for the paucity of such cases is easy enough to explain. Since the remedy provides going concern value and the shareholders are in fact receiving the higher amount (third-party sale value), the likely award in appraisal will be a lower amount than the dissenting shareholder will receive by voting in favor of the merger and taking the merger price. ${ }^{97}$ Where the case does occur is in those situations where Seller Co. is closely held and there is no public market for the shares. Without any market benchmark, disagreements about the actual value of the company may span an especially broad range. The minority shareholder may believe that the company was incompletely shopped and that the resulting sale price was actually lower than going concern value. ${ }^{98}$

What policy concerns do we have in this situation with respect to the treatment of the minority shareholders? One concern might be that the controller in the closely held firm did not do a good job in selling the company. Any legal concern, however, is

95. Union Ill. 1995 Inv. Ltd. P’ship v. Union Fin. Group, Ltd., 847 A.2d 340, 356 (Del. Ch. 2003) (stating that "acquirers typically share a portion of synergies with sellers in sales transactions").

96. Only 9 of more than 45 Delaware appraisal cases since Weinberger arose out of arm's-length acquisitions.

97. Union Illinois exemplifies this treatment - unfortunate for the dissenting shareholders, to be sure, but appropriate in our view. Union Illinois, 847 A.2d at 364 (setting a merger price of $\$ 9.40$ per share, plus contingent payments, and an appraisal award of \$8.74 per share); see also Kleinwort Benson Ltd. v. Silgan Corp., Civ. A. No. 11107, 1995 WL 376911, at *1 (Del. Ch. June 15, 1995) (a merger price of $\$ 6.50$ per share and an appraisal award of \$5.94 per share). As we explain elsewhere, infra Part IV.A.3., the award in Gholl $v$. eMachines exceeded the merger price because of the court's view that the auction was improperly curtailed in favor of an insider bidder. Gholl v. eMachines, Civ. A. No. 19444-NC, 2004 WL 2847865, at *16 (Del. Ch. Nov. 24, 2004). Until the most recent reversal by the Delaware Supreme Court, the appraisal awards by the court of chancery in the Technicolor saga were similarly below the merger price. Cede \& Co. v. Technicolor, Inc., Civ. A. No. 7129, 2003 WL 23700218 (Del. Ch. Dec. 31, 2003), rev'd, 884 A.2d 26 (Del. 2005) (setting a merger price of \$23 per share and an appraisal award of \$21.98 per share, which was raised on appeal to \$28.10 per share). Like Gholl, however, Technicolor can easily be seen as a case in which the ultimate award exceeded the merger price because of some judicial concern about the efficacy of the sale process. See Cede \& Co. v. Technicolor, Inc., 634 A.2d 345, 369-70 (Del. 1993). Similarly idiosyncratic reasons largely explain the fact that in other arm's-length merger appraisal cases, appraisal awards have run from $12.5 \%$ to $247 \%$ above the merger consideration. See Prescott Group Small Cap, L.P. v. Coleman Co., Civ. A. No. 17802, 2004 WL 2059515, at *35 (Del. Ch. Sept. 8, 2004) (determining the $247 \%$ premium by reference to the merger date value of Sunbeam common stock given as consideration in the merger, where the back-end merger was delayed for almost two years because of accounting fraud); Gentile v. SinglePoint Fin., Inc., Civ. A. No. 18677-NC, 2003 WL 1240504, at*7 (Del. Ch. Mar. 5, 2003) (awarding a 124\% premium over the estimated value of acquirer's stock paid in the merger, where the respondent did not defend the litigation and did not present a valuation case); Gilbert v. M.P.M. Enters., Inc., 709 A.2d 663 (Del. Ch. 1997), aff'd, 731 A.2d 790 (Del. 1999) (finding that the merger consideration included both an up-front cash payment and even larger potential future earnout payments and setting the appraisal award above the up-front cash component by 149\%); Cooper v. Pabst Brewing Co., No. 7244, 1993 WL 208763, at *8 (Del. Ch. June 8, 1993) (setting the appraisal award at 12.5\% over the second-step merger price, but the second step was the back end of a front-loaded bid with a blended value of $\$ 29.50$, which was $\$ 2.50$ greater than the amount of the appraisal award).

98. See Gholl, 2004 WL 2847865, at *15-16. 
mitigated by the fact that absent evidence to the contrary, the interests of the controller and the minority shareholders are aligned. Markets rather than courts are better at judging the adequacy of third-party sale values. As a result, the appraisal remedy in this context is truly an extra remedy above and beyond what the minority shareholder might otherwise expect.

One might ask why the appraisal valuation standard in this case should not be thirdparty sale value, since the company is indeed being sold. One answer is the legal onethe governing statute says that value created by the merger should not be included in valuing the firm. The economic answer is the same. If the value of the synergies were to be included in the fair value calculation, then mergers would not take place since the buyer would have to part with all of the benefits of the merger. Moreover, if such a rule were in place, there would be no incentives for potential buyers to expend the resources to identify possible merger opportunities.

Leaving the legal rule as going concern value, however, does not mean that the minority shareholders will not get some of the value of the synergies. If the merger is arm's-length then the buyer and seller will apportion the value of the synergies between them. In fact there is substantial evidence that much of the synergistic value arising from the merger is captured by the selling shareholders. ${ }^{99}$ But the sharing of the gains should be and can be fairly decided by the market and by the negotiators who represent the parties. In other words, the shareholders effectively receive the third-party sale value as a result of the agreement between the third-party buyer and the controller.

\section{Category 2: Squeeze-Out Merger Where the Company Will Continue to be Operated as Before the Merger}

The second category is a very different one. Now it is the managers, typically the controllers, of the corporation who are squeezing out the minority shareholders. In this second category, the evidence indicates that the company will be run in the same way after the squeeze-out as before. For example, the squeeze-out may be related to disagreements between the controller and minority shareholders in a close corporation, which hurt the company's performance. Alternatively, the transaction may take a public company private in order to avoid the costs associated with remaining public. ${ }^{100}$

In these cases, there is likely to be increased profitability, but the increase in profits is directly related to the recapitalization, not to a change of corporate policy with respect to investment in assets. The presumed gain in profits, however, carries increased risk, taken by the resulting less-diversified controller.

There is still a host of measurement problems involved in the DCF-based calculation of the value of the firm. The company, with all of its warts and diamonds, is valued in terms of the discounted free cash flow generated by the company's assets and reinvestment opportunities. In measuring the value of the warts and diamonds, the warts are valued as warts and the diamonds as diamonds. The minority shareholders cannot claim that if the company was run differently, or if a third party owned it, the warts

99. See Gregor Andrade et al., New Evidence and Perspectives on Mergers, 15 J. ECON. PERSP. 103, 112 (2001); Sara B. Moeller et al., Do Shareholders of Acquiring Firms Gain From Acquisitions? 32 tbl.4 (Nat'l Bureau of Econ. Research, Working Paper No. 9523, 2003), available at http://ssrn.com/abstract=383560.

100. See Koenig, supra note 8, at 512-13. 
would become diamonds. That may be correct as a factual matter, but it is irrelevant to the valuation issue. The minority's claim is equal to the value of the shares into the future, and that value is a mix of the existing warts and diamonds.

Similarly, the controller cannot claim that the diamonds are really warts. More specifically, if the company already has reinvestment plans that would fix current problems, the value reflects the value of those plans of the company as an operating concern.

The second category highlights the need for going concern value rather than thirdparty sale value. If the latter was the standard, the value enhancing transactions might not occur because the controller is not selling the firm and it may not be realizing anywhere near the benefits that a judge might decide would constitute third-party sale value.

But what if the controller is up to no good after all? At one level, the answer to this question is that appraisal is not the remedy designed for this problem. The issue is better handled as a suit alleging breach of fiduciary duty. However, we also believe that our method for calculating going concern value, which highlights any reinvestment plans that may already be in the works, reduces this problem. ${ }^{101}$

The serious cynic would respond that our proposal, with its focus on pre-merger reinvestment plans, fails to acknowledge that the controlling shareholder could keep such plans a secret until the appraisal proceeding concludes, thereby preventing the minority shareholders and the courts from accounting for those plans' values. Several reasons, however, suggest that this sort of concealment would be unlikely. First, document discovery can ordinarily yield evidence of any significant pre-merger business planning by the controlling shareholder. Also, it seems unlikely that such planning could be meaningfully undertaken without some related documentation generation. Second, it would be impractical—indeed, downright costly_for a controlling shareholder to delay any implementation of a valuable reinvestment and change in operations for the three years or so during appraisal proceedings. ${ }^{102}$ Third, courts sensitive to the potential for concealment and delay of pre-merger reinvestment plans could and should be liberal in permitting discovery of post-merger operational changes, at least in situations involving squeeze-outs by controlling shareholders. ${ }^{103}$

101. See infra Part IV.D.

102. The average duration of the Delaware appraisal cases since 1983 (when Weinberger was decided), from transaction date to date of award, has been approximately five years. Even excluding outlier cases lasting over ten years, such as Technicolor, which has been going on for more than 22 years, the average appraisal proceeding lasts nearly four years (about three years, ten months). For purposes of this discussion, of course, the relevant duration is the period from the transaction through the close of discovery. The latter benchmark surely occurs earlier than the award itself, but the observed length of the overall proceedings suggests that discovery in appraisal proceedings continues for a long time after the merger.

103. The Delaware courts have in fact shown considerable liberality regarding discovery of post-merger events. See, e.g., Cede \& Co. v. Technicolor, Inc., 758 A.2d 485, 499 n.91 (Del. 2000); Gonsalves v. Straight Arrow Publishers, Inc., 701 A.2d 357, 362 (Del. 1997) (“[P]ost-merger evidence is not necessarily inadmissible to show that plans in effect at the time of the merger have born [into] fruition.”); In re Best Lock Corp. S'holder Litig., Civ. A. No. 16281, 2000 WL 1876460, at*5-6 (Del. Ch. Dec. 18, 2000) (“Cede, in particular, as well as other cases, ha[s] relaxed significantly the limitations on discovery of post-merger evidence that may be admissible in certain circumstances even in appraisal cases that are statutorily limited to determining fair price at the time of the merger.”); Gower v. Beldock, Civ. A. No. 14387, 1998 WL 200267, at *3 (Del. Ch. Apr. 28, 1998) (allowing discovery of documents during the period of 27 months after the squeeze-out transaction); Cavalier Oil Corp. v. Harnett, Civ. A. No. 7959, 1988 WL 15816, at*14 (Del. Ch. Feb. 22, 1988) (stating that 
A final question is why the controller and not the minority shareholders get the benefits that make the squeeze-out profitable. Again, the benefits are those arising from the recapitalization. This is a subtle issue, but our earlier discussion of agency costs supplies an answer. As previously explained, from a finance perspective the controller who first takes a firm public sells the shares at a discount reflecting the agency costs that will arise in public ownership. In going private, the controller is simply recapturing the value of those costs. Having bought the shares at a discount, reflecting the agency costs, the minority shareholders do not get to capture those costs when the firm goes public. ${ }^{104}$ The case law answer, as we shall see, is more confused, but the short answer is that agency costs are an ongoing cost of the firm in its pre-squeeze-out existence. In a DCF calculation, the agency costs appear as higher management costs, perhaps due to slack in how tightly other costs are controlled, and due to other reasons. In other words, agency costs are real costs of doing business and thus are built into the DCF calculation.

\section{Category 3: Squeeze-Out Merger Where the Company Will be Operated Differently}

The third category is the difficult one that generates the cases that are conceptually complicated (as distinct from measurement complicated). As in the cases in the second category, the controller is unilaterally implementing the cash-out merger. Unlike the cases in the second category, however, there is evidence that the controller's plans call for different types of investments that would make the company more profitable and arguably different from the current company. This aspect makes this category of cases similar to those in the first category.

The law awards going concern value in all three categories. In the first category, however, the minority shareholders receive something akin to third-party sale value through the workings of the market mechanism. In the second category, the minority shareholders receive no benefits from the squeeze-out, largely because the only benefits are those associated with the recapitalization itself. The company's operations will not become more efficient. How do the minority shareholders fare when going concern value is applied in the third category?

"post-merger data may be considered" if it meets the Weinberger standard pertaining to non-speculative evidence), aff'd, 564 A.2d 1137 (Del. 1989); Dalton v. Am. Inv. Co., Civ. A. No. 6305, 1983 WL 18009 (Del. Ch. Nov. 16, 1983) (allowing discovery of certain documents for up to 36 months after the merger); Ross v. Proco Mgmt., Inc., Civ. A. No. 6146, 1983 WL 17991 (Del. Ch. May 25, 1983); Kaye v. Pantone, Inc., Civ. A. No. 1981 WL 15072 (Del. Ch. Oct. 6, 1981) (permitting discovery of documents generated up to three years after a merger because such post-merger evidence might prove the value of matters that were in progress prior to the merger); Tannetics, Inc. v. A.J. Indus., Inc., Civ. A. No. 5306, 1979 WL 2700, at *4 (Del. Ch. July 17, 1979) (taking into account a contract that was awarded after the merger because established "market dominance" was held to have assured its award). Even the most restrictive of the Delaware cases allowed discovery of information for the period of a year following the merger. Lane v. Cancer Treatment Ctrs. of Am., Inc., Civ. A. No. 12207, 1994 WL 263558, at*4 (Del. Ch. May 25, 1994).

104. Compare Brett A. Margolin \& Samuel J. Kursh, The Economics of Delaware Fair Value, 30 DEL. J. CORP. L. 413, 434 (2005) (acknowledging that expected agency costs are impounded in the market price of the firm's shares, but positing that fair value should be determined without netting such agency costs in order "to enforce the promises by which the corporation induces higher stock prices”). We disagree with Margolin and Kursh because shares cannot be sold, and do not trade, at levels that fail to account for expected agency costs. Any fair value awarded that compensated for expected agency costs would therefore confer a windfall upon minority shareholders. See supra Part III.C. 
How should the potential increase in valuation be handled in the case where the squeeze-out is being done by the current controller? Here, there is an air of inequity. In the first category, the benefits are brought to the table by the third party. Even so, the minority shareholders gain. Here, the gains are brought to the table by the controller who, prior to the squeeze-out, had a fiduciary duty to the minority shareholders. Who walks away with the profit? If the controller could simply choose the moment to squeeze out the minority when the fortune of the firm was about to improve, the result would be to discourage minority shareholders from becoming minority shareholders and upset the balance that protects minority shareholders while allowing the controller to retain the benefits of control.

This problem is illustrated in the well-known cornfield story, or at least our version of the story. ${ }^{105}$ The story begins with a cornfield that is the only asset owned by the corporation. At the present time, the asset is worth $\$ 50$ million as a cornfield, which is thus the value of the company. The controller, who is also the CEO, comes to recognize a new investment opportunity that can profitably turn the cornfield into a valuable office building. Before taking the required actions to accomplish that conversion, the CEOcontroller decides to squeeze out the minority shareholders in a merger, converting the minority shares into cash equal to the pro rata value of $\$ 50$ million, the value of the company managed as a cornfield. It is known that the value of the company will be $\$ 60$ million after the conversion. As mentioned in Part II, the statute suggests that the increase in value arising from a merger cannot be included in the appraised value. The Delaware Supreme Court's pronouncement in Weinberger, however, seems superficially inconsistent and overly broad, by instructing that those values must be included if they are non-speculative.

In our view, any inconsistency is resolved in light of a more nuanced appreciation of the pertinent finance perspective, and an introduction of principles of the corporate opportunity doctrine. From a finance perspective, the value of the company in appraisal is the full $\$ 60$ million, given the critical assumption that the opportunity arises and the plan to develop the cornfield is made prior to the merger. Remember that the company is worth not only the present value of the free cash flow from its current assets, but also the free cash flows generated by the reinvestment strategy that it pursues. The development of the cornfield is a reinvestment of the company's free cash flow and, although the actual investments are not made until after the squeeze-out, the plans are in place before the squeeze-out. In the finance calculation, the fact that the investment is made after the squeeze-out is not a complexity since the entire value of the corporation depends on the future free cash flows. Nor is it a complexity that the asset (the office building) will not be built for a number of years. Again, the value of the firm in appraisal includes the value of reinvestments made annually into the future.

A legal perspective yields the same result. Assumed in the above hypothetical are several elements that are critical in the legal doctrine of corporate opportunity. The cornfield is owned by the corporation and the controller arrives at her plans to develop the cornfield while serving as the CEO. The other key assumption is that the plan is made prior to the squeeze-out, although the plan may not become operational until after the

105. Symposium, Delaware Appraisals After Cede \& Co. v. Technicolor, Inc., 17 BANK \& CoRP. GOVERNANCE L. REP. 631 (1996). 
squeeze-out is accomplished. Given these assumptions, the corporate opportunity doctrine would strongly suggest that the potential development of the cornfield into an office building is an opportunity that belongs to the corporation and should therefore be considered part of the nature of the corporate enterprise at the time of the merger.

If we change these two assumptions, the result is arguably different, both from a finance perspective and a legal perspective. If the controller has the extra time and an employment contract that permits her to work outside of the company, she can buy other cornfields and turn them into office complexes. In this case, the plan to develop the cornfield is not part of the company's corporate policy. If the controller decides to squeeze out the minority and plans to continue to run the company as a cornfield, then the company's going concern value is still worth only $\$ 50$ million. In this alternative scenario, there is nothing special about the cornfield, so that a lot of alternative underutilized land could be developed by the enterprising controller with extra time on her hands. The squeeze-out merger, when it occurs, is not necessary to enable the controller to turn a cornfield into an office building. The only caution here is the obvious one that arises if and to the extent that the squeeze-out is necessary to enable the controller to turn some other cornfield into an office building. ${ }^{106}$

The financial valuation comes to a very different result when we change the assumption about the timing of the decision. Where there is no evidence that the controller is even considering using the company's free cash flow to build the office building - presumably because she does not see the new opportunity or because no such opportunity has arisen-and will plow any undistributed free cash flows back into the cornfield, then we are clearly back into a category 2 situation (squeeze-out with no change in operations) and the company is worth only $\$ 50$ million in appraisal.

Based on these hypotheticals, one might conclude that the controller in the second situation, who leaves the cornfield as a cornfield, comes across as a short-sighted manager for not seizing the new investment opportunity. On the other hand, the manager may believe that the investment opportunity does not actually exist and that turning the cornfield into an office building is truly a bad investment that would result in a company worth less than $\$ 50$ million. ${ }^{107}$ But appraisal and finance are not meant to solve any management problems. The minority shareholder who bought into the company with the current cautious manager gets the value of the company as it is managed by the cautious manager. The minority shareholder cannot claim that warts should be turned into diamonds and valued as such. The minority shareholder gets the value of the firm with its cornfield.

The problem, of course, is that minority shareholders have incentives to envision

106. A separate problem arises if the controller owns multiple cornfields, but has only one opportunity to develop an office building, and must choose which cornfield to convert. This is a problem confronted in the corporate opportunity doctrine, where a director or officer is a fiduciary for multiple corporations. See, e.g., Johnston v. Greene, 121 A.2d 919, 924 (Del. Ch. 1956) (discussing a director's fiduciary duty to offer up an investment opportunity to the corporation when he is a director of multiple corporations); Burg v. Horn, 380 F.2d 897, 900-01 (2d Cir. 1967) (same). As we explain below, whatever resolution the doctrine of corporate opportunity supplies in this situation should also provide useful guidance in resolving the "fair value" gain inclusion issue in the scenarios we discuss.

107. Although the original hypothetical had the cornfield in the middle of New York City, it is more likely that the cornfield is in one of the southern counties of New Jersey where corn is grown and land is cheap. 
corporate diamonds when there are, in fact, only corporate warts. The law correctly does not open the appraisal remedy to the claims of minority shareholders that the company would be more valuable if only their ideas had become corporate policy and the warts had been transformed into diamonds.

One can question whether our method for reconciling the statute and case law with finance provides sufficient protection of minority shareholders. The answer is that it provides a good deal of protection in the appraisal setting. If the minority shareholder believes that the controller's behavior constitutes a breach of the duty of loyalty or good faith, the shareholder can also mount a case that seeks a remedy for the breach. If the facts of the case are of a "cornfield to office building" investment that is truly an excellent opportunity, yet is foregone by the controller until after a squeeze-out, there is certainly more than a hint of breach of the duty of loyalty. At the very least, however, the minority shareholder will be able to recover a proportionate share of the benefits, discounted to present value, that are reasonably expected to be generated by the company based on its existing assets and its expected reinvestment opportunities.

\section{Delaware Case LaW Corroborates the Proposed TheORETICAL FrameWORK}

In the preceding section we developed an approach to measuring fair value when shareholders objecting to a merger seek an appraisal remedy. We believe that those assertions are consistent with the Delaware case law defining the concept of "fair value" for purposes of Delaware's appraisal statute. In several instances, in fact, we believe that our approach simply echoes settled judicial articulations of valuation standards. In other cases, however, we believe that the case law, while not inconsistent with our approach, has not fully developed appropriate doctrinal guidance. In this section we analyze the extent to which case law is consistent with the conclusions we reached in the prior section and offer, where relevant, guidance for use in future cases.

\section{A. Category 1 Cases}

"Fair value" in a sale to a third party excludes any gains arising from the merger and is not equivalent to third-party sale value. However, third-party sale value minus synergies is informative of fair value except when the sale process is flawed.

\section{Gains Arising from the Merger: Synergistic/Combinatorial Benefits}

Of all the claims we make, the assertion that "fair value" excludes gains arising from the merger itself is the most clearly established and visible in Delaware law. That assertion, after all, is precisely what the governing statute says. Section 262(h) of the DGCL prescribes a determination of "fair value" that excludes "any element of value arising from the accomplishment or expectation of the merger." 108 This prohibition excludes from "fair value" gains associated with the combination of two enterprises whose merger gives rise to the valuation proceeding. Such excluded gains include, for example, those resulting from economies of scale or increased market share, or those that derive from the acquirer's plans to operate the post-merger enterprise more efficiently.

108. DeL. CODE ANN. tit. 8, § 262(h) (2005). 
Representative of the cases reflecting this application of section 262(h)'s prohibition is Union Illinois, in which the court determined "fair value" by reference to the merger price, but net of estimated synergies. ${ }^{109}$ The court explained this subtraction of anticipated synergies as follows:

The exclusion of synergy value . . . derives from the mandate that the subject company in an appraisal be valued as a going concern. Logically, if this mandate is to be faithfully followed, this court must endeavor to exclude from any appraisal award the amount of any value that the selling company's shareholders would receive because a buyer intends to operate the subject company, not as a stand-alone going concern, but as a part of a larger enterprise, from which synergistic gains can be extracted. ${ }^{110}$

Through a wooden interpretation, one could draw a contrary inference from the previously quoted language, as in Weinberger, where the Delaware Supreme Court, in interpreting the scope of the section 262(h) exclusion, stated that "elements of future value, including the nature of the enterprise, which are known or susceptible of proof as of the date of the merger and not the product of speculation, may be considered."111 This language, heavily emphasized in the Delaware Supreme Court's subsequent opinion in Technicolor would literally permit a dissenting shareholder to claim entitlement to a proportionate share of any future value arising from the merger-even economies of scale, for instance-as long as such future value were not "speculative" at the date of the merger. 112

We believe, however, that such a literal reading is not required by the court's statements in Weinberger and Technicolor, and that it is intolerably inconsistent with the language of section 262(h) itself. Certainly, the Delaware courts themselves have not subsequently embraced such a reading. No case, to our knowledge, holds that nonspeculative synergistic merger gains should be shared with dissenting stockholders in all cases. To the contrary, the Union Illinois opinion embraces the view we support. ${ }^{113}$

We find further support for that view in then Vice Chancellor (now Justice) Jacobs's opinion in Allenson v. Midway Airlines Corp. ${ }^{114}$ In that case, the merger was part of a package of significant debt concessions and equity infusions for a company that was on the verge of bankruptcy. ${ }^{115}$ All of those concessions and infusions were contractually committed to before the merger, and were thus anything but "speculative," but they were explicitly contingent upon, and would not occur until after, completion of the merger. ${ }^{116}$ Despite the plainly nonspeculative character of the merger-related benefits, the court declined to include those benefits in determining "fair value." 117 That ruling followed, as the court explained it, from the fact that the corporation and its controlling shareholder "neither possessed nor exercised the legal power to implement the Concessions on or

109. Union Ill. 1995 Inv. Ltd. P’ship v. Union Fin. Group, Ltd., 847 A.2d 340, 364 (Del. Ch. 2003).

110. Id. at 356.

111. Weinberger v. UOP, Inc., 457 A.2d 701, 713 (Del. 1983)

112. Cede \& Co. v. Technicolor, Inc., 684 A.2d 289, 297 (Del. 1996).

113. Union Ill., 847 A.2d at 340.

114. Allenson v. Midway Airlines Corp., 789 A.2d 572 (Del. Ch. 2001).

115. Id. at 572-73.

116. Id. at 573 .

117. Id. at 585-86. 
before the merger date.”118

In so ruling, the court distinguished the Delaware Supreme Court's opinion in Technicolor, which relied heavily upon the language in Weinberger quoted above. ${ }^{119}$ The key distinction noted in Allenson is the fact that in Technicolor, the acquirer had begun to implement its business plan before the merger, and thereby "had subjected the corporation's minority stockholders to the economic risks that plan posed."120 In contrast, any value attributable to the concessions and equity infusions in Allenson "would exist only if and after the merger occurred."121

The statute supported by the cases thus holds to the position that synergistic gains that only occur after the merger, and would not occur otherwise, are not part of the fair value or going concern value of the enterprise being appraised. This is in line with the traditional efficiency view that the synergistic bidder who can enhance the efficiency of the company's assets cannot be required to pay the value of those gains to the current owners lest the bidder not bid and the gains not occur.

\section{Gains Arising From the Merger: Acquirer's New Business Plans}

Allenson offers another important implication on a point distinct from the matter of synergistic or combinatorial merger gains that we have been addressing: namely, the question of whether value derived from a third-party acquirer's new business plans may be included in determining the "fair value" of dissenting shares. ${ }^{122}$ In our view, Allenson's distinction of Technicolor implies that as long as the operational risks of the acquirer's new business plans are not imposed upon minority shareholders before the merger, any value derived from those revised business plans is excluded from "fair value" by the language of section 262(h). ${ }^{123}$ That view is also well grounded in the Delaware Supreme Court's opinion in Technicolor. In that case the supreme court emphatically reaffirmed that "fair value" must be measured by reference to "value attributable to the going concern, i.e., the extant 'nature of the enterprise,' on the date of the merger." 124 The only apparent reason for the supreme court's reversal was its

118. Id. at 585.

119. Allenson, 789 A.2d at 585.

120. Id.

121. Id. at 585-86.

122. Id. at 586 .

123. Del. Code ANN. tit. 8, § 262(h) (2005).

124. Cede \& Co. v. Technicolor, Inc., 684 A.2d 289, 298 (Del. 1996). Thus, the supreme court's Technicolor opinion, supports, rather than undermines, Chancellor Allen's reasoning underlying his holding that an acquirer's post-merger business plan is ordinarily not to be taken into account in determining fair value. Id. In his opinion, Chancellor Allen reasoned as follows:

[V]alue that arises only from the acquiror's utilization of the acquired company's assets following a merger is, under the statutory language, not a value in which a dissenting shareholder is entitled to share as part of "his proportionate interest in a going concern". . . . Our statute and a long line of cases that focus our inquiry on "going concern" value recognize that the value that is relevant in an appraisal is the value of the assets in the way they are deployed in the corporation from which the shareholder will exit.

Cede \& Co. v. Technicolor, Inc., Civ. A. No. 1990, 1990 WL 161084, at *20 (Del. Ch. Oct. 19, 1990). That ruling relied heavily on the Delaware Supreme Court's opinion in Bell v. Kirby Lumber Corp., 413 A.2d 137, 142 (Del. 1980), in which that court rejected a valuation approach premised on liquidation by a third-party 
perception that on the facts of the case, Technicolor was already operating under the acquirer's business plan as of the merger date. ${ }^{125}$

We conclude from these rulings, and from the statutory exclusion that they interpret, that synergies dependent on the consummation of an arm's-length acquisition or combination may not contribute to "fair value" in appraisal proceedings. ${ }^{126}$ Similarly, we conclude that operating efficiencies that arise from the acquirer's new business plans are not properly included in determining "fair value," as long as they are not operationally implemented before the merger, even though they derive solely from the enterprise's own assets.

\section{The Role of Third-Party Sale Value}

The statutorily-based exclusion of synergistic merger gains and gains derived from a new acquirer's alternative business strategies has led to a series of pronouncements in the Delaware case law to the effect that the liquidation value of the corporation's assets cannot be the exclusive measure of "fair value" in an appraisal proceeding in which the corporation will valued as a going concern. ${ }^{127}$ Despite the fact that the liquidation value of corporate assets is not necessarily the same as third-party sale value, many Delaware cases decline to equate "fair value" with the value that might be achieved in a

acquirer because that approach "presupposes . . . that the company will not continue in business on the same basis that existed immediately prior to the merger.” Id. at 142 (quoting Application of Del. Racing Ass'n, 213 A.2d 203, 207-08 (Del. 1965)). In our view, this reasoning also effectively refutes criticism of the court's decision in Allenson. See Ryan W. Koppelman, Including Non-Speculative Future Value in Delaware Appraisal Proceedings: Why the Chancery Court in Allenson Got it Wrong, 2 DEPAUL BUS. \& CoM. L.J. 341 (2004) (urging that because the concessions were committed to before the merger they were non-speculative and therefore should have been taken into account in determining fair value).

125. Technicolor, 684 A.2d at 299.

126. This view was also the consensus of a group of Delaware practitioners who met in 1996 to discuss the implications of the then recent Technicolor opinion. See Symposium, supra note 105, at 641-42, which recounts the following exchange:

PROFESSOR [LAWRENCE] HAMERMESH: . . . [Y]ou are both satisfied that the kind of synergy that I'm talking about arising from cost reductions due to the combination are values that arise from the accomplishment or expectation of the merger. And even though they are not speculative, they need to be excluded in the dissenting stockholders' appraisal proceeding?

MR. [DAVID] McBRIDE: Yes. Although I accept the proposition that the language of the Supreme Court opinion seems to suggest that future value that's not speculative can be considered, I just don't believe that the Supreme Court had this sort of hypothetical in mind.

MR. [A. GILCHRIST] SPARKS: I'm in complete agreement with the two of them, and I get there through the same thought processes; namely, that synergies, the opportunity to save money on an accountant that you can eliminate only if the merger goes forward, are not included in the appraisal.

The reason for that is that until the merger actually takes place, that is not part of the "nature of the enterprise." That saving is just not available to the corporation until the merger actually takes place.

Id.

127. Technicolor, 684 A.2d at 298; In re Shell Oil Co., 607 A.2d 1213, 1219 (Del. 1992); Rapid-Am. Corp. v. Harris, 603 A.2d 796, 802-03 (Del. 1992) (“The dissenting shareholders are entitled to receive 'fair value' representing their 'proportionate interest in a going concern.’” (quoting Cavalier Oil Corp. v. Harnett, 564 A.2d 1137, 1144 (Del. 1989))); Kirby Lumber Corp., 413 A.2d at 140-42. 
hypothetical sale of the company. ${ }^{128}$ We do not quarrel with either of these general case law pronouncements.

On the other hand, the rejection of sale value as an exclusive measure of fair value in appraisal does not mean that sale value is entirely irrelevant in determining fair value. Even in Kirby Lumber, the Delaware Supreme Court approved the use of a liquidation valuation of the corporation's assets as a significant, albeit nonexclusive, measure of "fair value."129 And as demonstrated more recently in the court of chancery's excellent discussion of the issue in Union Illinois, third-party sale value can be a cornerstone of an analysis of fair value as long as synergies are subtracted. In that case Union Financial Group was sold to a third-party buyer in a deal that called for an immediate cash payment of $\$ 9.40$ per share and other payments if certain contingencies were met. ${ }^{130}$ The court concluded that the company was sold in "a competitive and fair auction, which followed a more-than-adequate sales process and involved the broad dissemination of confidential information to a large number of prospective buyers." ${ }^{131}$ The Vice Chancellor then concluded that he should not second guess the outcome of an auction-determined price, and concluded that the fair value was the merger price minus an estimate of the synergies. ${ }^{132}$ By taking this approach, he awarded the minority shareholders less than they would have received had they taken the merger price. Importantly, the Vice Chancellor also concluded that the minority shareholders presented no reliable alternative estimates of fair value. ${ }^{133}$

128. See Agranoff v. Miller, 791 A.2d 880, 899 (Del. Ch. 2001) (“[T]o exclude value that derives from the expectation of a synergistic change in control[, this court has] used a necessarily rough approach that simply involves shaving some percentage off the top of the available information about control premiums paid.”); ONTI, Inc. v. Integra Bank, 751 A.2d 904, 913 (Del. Ch. 1999) (“[T]his Court will make adjustments for the effect of a control premium when it depresses the market value of minority-owned shares, but it will not specifically consider studies of control premiums paid in merger transactions because those reflect expected future profits after the merger (i.e., synergy values).”); Kleinwort Benson Ltd. v. Silgan Corp., Civ. A. No. 11107, 1995 WL 376911, at *3 (Del. Ch. June 15, 1995) (“[T]his Court has rejected the use of a control premium derived from merger and acquisition data because the control premium incorporates post-merger value.” (citing Salomon Bros., Inc. v. Interstate Bakeries Corp., Civ. A. No. 10054, 1992 WL 94367, at *6 (Del. Ch. May 1, 1992))); Cooper v. Pabst Brewing Corp., Civ. A. No. 7244, 1993 WL 208763, at *8-9 (Del. Ch. June 8, 1993); see also Cede \& Co. v. JRC Acquisition Corp., Civ. A. No. 18648-NC, 2004 WL 286963, at*7 (Del. Ch. Feb. 10, 2004) (relying on the corporation's actual debt to equity ratio rather than the industry norm, "because an appraisal proceeding does 'not attempt[] to determine the potential maximum value of the company”” (citing In re Radiology Assocs., Inc., 611 A.2d 485, 494 (Del. Ch. 1991))). "Plaintiff is not entitled to the proportionate sales value of Radiology. Plaintiff is entitled to the proportionate value of Radiology as a continuing shareholder." Id.

129. Kirby Lumber Corp., 413 A.2d at 146 (approving a 40\% weighting of asset liquidation in determining fair value).

130. Union Ill. 1995 Inv. Ltd. P’ship v. Union Fin. Group, Ltd., 847 A.2d 340, 349 (Del. Ch. 2003).

131. Id. at 358 .

132. Id. at 359.

133. The Delaware Supreme Court has formulated the burden of proof in a slightly different way than the articulation in Union Illinois. In M.P.M. Enterprises, the court expressed concern that acceptance of the merger consideration as a proxy for "fair value," without corroboration by other evidence, might inappropriately incorporate synergies or other considerations peculiar to the specific buyer. M.P.M. Enters., Inc. v. Gilbert, 731 A.2d 790, 797 (Del. 1999).

A merger price resulting from arms-length negotiations where there are no claims of collusion is a very strong indication of fair value. But in an appraisal action, that merger price must be 
As a measure of "fair value," third-party sale value is not and should not be automatically applied. In Gholl $v$. eMachines, Inc, ${ }^{134}$ for example, the court found that the auction leading to the sale of the company was not effective because it was terminated too early and without reason, perhaps because the winning bidder was an inside director. In this case, the court reasonably concluded that fair value was above the merger price even if the merger price did include synergies. ${ }^{135}$

Broadly interpreted, these cases stand for the principle that in a fair and effective auction with full information, the merger price minus the synergies is the best estimate of fair value ${ }^{136}$ in the category 1 type of cases addressed in this Part. ${ }^{137}$ Where the auction is defective, however, the merger price minus synergies does not provide a reliable estimate of fair value.

There is much to be said for the clarity that recent cases bring to fair value determinations in third-party acquisitions. ${ }^{138}$ Specifically, the price achieved in a full and effective sale process, minus the value of the synergies of the transaction, should be accepted as providing a reliable estimate of fair value. Although the value of the synergies could still be debated, no informed dissenting shareholder would bring suit in such a case since the merger price becomes the effective ceiling, and thus, the minority shareholders would accept the sale price rather than seek appraisal.

accompanied by evidence tending to show that it represents the going concern value of the company rather than just the value of the company to one specific buyer.

Id. We believe, however, that the court in Union Illinois dealt appropriately with this concern through its insistence on excluding deal-specific synergies in determining fair value.

134. Gholl v. eMachines, Inc., Civ. A. No. 19444-NC, 2004 WL 2847865, at*15 (Del. Ch. Nov. 24, 2004).

135. Id. There seems to be little or no evidence in the case to suggest that the merger price did include synergies: the winning bidder was an inside director, rather than a strategic buyer, and there was no indication that the director had adopted any plans to alter the ongoing operations of the enterprise.

136. Id. at *60-61 ("Price derived from a competitive and fair auction is strong evidence of fair value." (citing Union Illinois, 847 A.2d at 357)). This is not to say that third-party sale value, net of estimated synergies, is invariably an accurate assessment of fair value. It is possible for bidders to overpay, for a number of reasons. Applying third-party sale value, net of synergies, however, at least affords the assurance that dissenting shareholders would always be better off accepting the merger price following an effective auction. See, e.g., Union Illinois, 847 A.2d at 356 ("[T]he fair value standard operates to leave the . . petitioners . . . with less than they would have received had they accepted the Merger consideration.”). The problem of overcompensation in appraisal proceedings is therefore likely to be trivial or nonexistent.

137. We acknowledge that Gholl v. eMachines does not fit perfectly within any of the three categories we outlined in Part III. Because it involved a director and founder acquiring the other stockholders' shares for cash, it resembles "going private" mergers effected by controlling stockholders, the situations addressed in categories 2 and 3. Because of the absence of any suggestion in the case that the director-bidder intended to alter the operations of the company following the merger, we are inclined not to view the case as belonging to our category 3; and because there was no suggestion in the case that the director-bidder expected to achieve any gains arising from the recapitalization effected by the merger itself, we are not inclined to view the case as a category 2 case either.

138. We are less enthusiastic about the assertion — now routine in the case law and even in expert testimony in many appraisal cases - that public share market prices invariably fall short of fair value or going concern value, to the extent of some "implicit minority discount.” See, e.g., Prescott Group Small Cap, L.P. v. Coleman Co., Civ. A. No. 17802, 2004 WL 2059515, at *28-29 (citing M.G. Bancorporation, Inc. v. LeBeau, 737 A.2d 513, 522-23 \& n.26 (Del. 1999)). The reasons for that lack of enthusiasm are not developed in this Article, but several commentators have begun to explore them. See, e.g., Richard A. Booth, Minority Discounts and Control Premiums in Appraisal Proceedings, 57 Bus. LAW. 127, 150-51 nn.130, 155 (2001); Coates, supra note 91, at 1279 n.92. 
However, no such inference should be drawn when the sale process is defective in any material way or reliable DCF estimates provide conflicting information. Consequently, appraisal in third-party sales would focus on the appropriate issue of the validity of the sale process. The dissenting shareholders need not prove breach of fiduciary duty, although such a claim is available to them, but only that the sale process was defective in some manner. The dissenting shareholders could also succeed if they were able to provide reliable DCF estimates that yielded a higher value than the sale price. We believe it is unlikely that such a reliable estimate does exist if the sale process was effective, but that avenue of analysis should be left open, in part because it serves as a check on the hasty acceptance of the sale process as effective.

\section{B. Category 2 Cases: Controlling Shareholder Squeeze-Out Merger/“Fair Value” Equals Going Concern Value Absent Planned Change of Business, and Not Hypothetical Third- Party Sale Value}

In contrast to the category 1 situation just reviewed, the merger effected by a controlling shareholder leaves no role for hypothetical third-party sale value in determining "fair value" in appraisal proceedings. As a matter of finance, 139 "fair value" should be determined on the basis of future free cash flows associated with the going concern, including the agency costs inherent in the enterprise prior to the merger. This view comports with the well-established principle of Delaware law that minority shareholders have no legal right to demand that the controlling shareholder achieve-and that they be paid — the value that might be obtained in a hypothetical third-party sale. ${ }^{140}$

Any temptation to resort to hypothetical third-party sale value may respond to the possibility that the controller has some disclosed or undisclosed plan to change the corporate enterprise following the merger (by sale, breakup, or otherwise) and thereby extract the maximum value from the enterprise, appropriating solely to itself the benefits of that change. We believe, however, that a blanket assumption or presumption of such a plan is unjustified. A number of appraisal cases arise in situations where the benefit to the majority shareholder is generated by the recapitalization associated with the squeeze-out and thereafter the firm will continue to be operated much as it had before. These scenarios are even more plausible in the case of a publicly held company, if one takes into account the potential benefits to the controlling shareholder of dispensing with reporting, governance, and other obligations associated with public minority ownership. ${ }^{141}$ We review below some of the Delaware cases in this category, in which

139. See supra Part III.B.2.

140. McMullin v. Beran, 765 A.2d 910, 919-20 (Del. 2000) (citing Bershad v. Curtiss-Wright Corp., 535 A.2d 840, 845 (Del. 1987)); Orman v. Cullman, Civ. A. No. 18039, 2004 WL 2348395, at *5 (Del. Ch. Oct. 20, 2004); Peter Schoenfeld Asset Mgmt., LLC v. Shaw, Civ. A. No. 20087-NC, WL 21649926, at *2 (Del. Ch. July 10, 2003), aff'd, No. 384,2003, 2003 WL 22998806840 (Del. Dec. 17, 2003).

141. See, e.g., Melinda Ligos, When Going Public May Not Be Worth It, N.Y. TimES, June 3, 2004, at C7 (describing scope of and reaction to enhanced compliance costs imposed by the Sarbanes-Oxley Act of 2002); Emily Thornton, A Little Privacy, Please, Bus. WK., May 24, 2004, at 74 (same); Adrian Michaels, Governance Costs Lead 20\% of Public Companies to Consider Going Private, FIN. TIMES (London), May 19, 2004, at 1 (same); Thomas E. Hartman, Foley \& Lardner LLP, The Cost of Being Public in the Era of Sarbanes-Oxley 12 (June 16, 2005), available at http://www.foley.com/files/tbl_s31Publications/FileUpload137/2777/2005\%20Cost\%20of\%20Being\%20Public 
the only apparently possible gains to be extracted from the merger arise because of the accomplishment of the merger itself.

\section{Kirby: The Foundational Case}

A leading example in this category, and the leading case declining to define "fair value" solely by reference to third-party sale value, is Bell v. Kirby Lumber Corp. ${ }^{142}$ In that case, the dissenting shareholders claimed that Kirby's timberland could be put to better use and asked that the shares be valued based on the liquidation or sale value of the timberland. The concern here is that after the merger, the controller would indeed put the company's land assets to a more immediately profitable use, depriving the minority of the benefit of that change. But there were no facts indicating that such a change in operations was planned or intended, and thus the court correctly declined to rely exclusively upon a liquidation or third-party sale value.

Indeed, by the time of the merger, the controlling shareholder (Santa Fe Industries) had already embarked upon a dramatic restructuring of the business of Kirby Lumber, involving construction of new production plants to draw upon and profit from the company's extensive timber resources. ${ }^{143}$ There is no indication that the controlling shareholder did anything in the years following the merger but continue to pursue that pre-merger restructuring plan. ${ }^{144}$ It seems unlikely at best, therefore, that the controlling shareholder in that case sought to affect the merger in an attempt to gain unfair advantage at the expense of the minority shareholders by means of a post-merger change in business plan. At worst, the controlling shareholder might have been taking advantage of shortcomings in the Delaware appraisal law that have long since been cured. ${ }^{145}$

\%20Final.pdf. (stating that $21 \%$ of public firms considered going private in 2004, up from 13\% in 2003).

142. Bell v. Kirby Lumber Corp., 413 A.2d 137 (Del. 1980). We examine below whether the judicial appraisal in Kirby Lumber employed appropriate techniques for determining the "fair value" of the shares subject to appraisal.

143. Bell v. Kirby Lumber Corp., 395 A.2d 730, 733 (Del. Ch. 1978), aff'd, 413 A.2d 137 (Del. Ch. 1980). There is no question, in light of Technicolor, that the "fair value" of Kirby Lumber shares would have to be determined in light of those significant operational changes and plans in place at the time of the merger.

144. James Cook, How the Santa Fe Woke Up, ForBES, Nov. 12, 1979, at 49 (describing program of plant and product expansion launched in the 1960s).

145. At the time Kirby Lumber was decided, the Delaware courts insisted that "earnings value," an analytical cousin to an evaluation based on discounted future returns, be calculated by reference to earnings in the full five years preceding the merger, and that was the approach used by the appraiser and the trial court, despite drastic changes in Kirby Lumber's business during that time frame. Kirby Lumber, 413 A.2d at 145. Thus, the parent company might have viewed a merger as an opportunity to pay a "fair value" that did not fully reflect the actual earnings potential of the subsidiary's openly disclosed and existing business plans. Id. In his concurring opinion, then Justice Quillen appeared to recognize this potential problem and presciently questioned the courts' insistence upon use of long-past earnings in determining “earnings value.”

[C]ounsel and the courts, through the flexibility implicit in the traditional standard, should encourage the legislatively established valuation process to be open to generally accepted techniques of evaluation used in other areas of business and law....

$\cdots$

. . . [I]n the exercise of independent trial judgment I may have concluded that the five-year averaging approach was inappropriate in this case.

Id. at 151 (Quillen, J., concurring). Justice Quillen's call for openness to generally accepted valuation 


\section{Kleinwort: Satisfying Conflicting Demands for Liquidity}

Kleinwort Benson ${ }^{146}$ represents a straightforward recapitalization, and there were no allegations that the company's assets would be used differently, and in a more valued manner, after the squeeze-out merger. On the facts reported, the motivation appears to be a financial restructuring. The Silgan Company was and would remain a container company after it merged into Silgan Holdings. Silgan had two classes of voting stock, A and B. The two controllers of Silgan, Philip Silver and Greg Horrigan, controlled 50\% of the board through their ownership of the A class stock and would continue to own $50 \%$ of Silgan Holdings after the merger. The merger would allow Morgan Stanley, which controlled the other board seats through its two-thirds ownership of the B class shares, to cash out at a mutually advantageous price. ${ }^{147}$ The petitioners, minority shareholders of the B class stock, believed that the company's shares were being undervalued. Their claim of undervaluation, however, did not rest on any presumed new use of the assets. Instead they claimed that the assets were being capitalized at a lower rate than the assets of other container companies.

\section{Borruso: Reconsolidating a Failing Subsidiary}

Borruso v. Communications Telesystems Int' $l^{148}$ represents another genre of cases that fits into our second category. In this type of case a failed subsidiary is being merged back into the parent company. In this particular case, both the parent (CTS) and the subsidiary (WXL) were privately held telephone companies. WXL was established to expand the parent's reach into Europe. When the subsidiary's revenue failed to meet minimal targets, the squeeze-out merger eliminated the subsidiary as an unprofitable independent company, a choice that was preferred to shutting the company down because of concern over the reputation of related company operations in other countries. The allegations in this case did not involve any claims that WXL's assets would be used differently or in a more valued manner after the squeeze-out merger. Rather the claim was that the purchase price was below the subsidiary's ongoing concern value. The Vice Chancellor agreed with the petitioners, finding that the merger price was determined in a

techniques anticipated the Delaware Supreme Court's landmark decision in Weinberger v. UOP, Inc., 457 A.2d 703 (Del. 1983), in which the court set in motion the modern practice of relying on DCF analyses in determining “fair value” in statutory appraisal proceedings. See, e.g., M.P.M. Enters. v. Gilbert, 731 A.2d 790, 793-95 (Del. 1999); Cede \& Co. v. JRC Acquisition Corp., Civ. A. No. 18648-NC, 2004 WL 286963 (Del. Ch. Feb. 10, 2004); Cede \& Co. v. Technicolor, Inc., Civ. A. No. 7129, 2003 WL 23700218, at*4 (Del. Ch. Dec. 31, 2003); ONTI, Inc. v. Integra Bank, 751 A.2d 904, 916 (Del. Ch. 1999); Odyssey Partners, L.P. v. Fleming Cos., 735 A.2d 386, 423 (Del. Ch. 1999); Hintmann v. Fred Weber, Inc., No. 12839, 1998 WL 83052, at *3 (Del. Ch. Feb. 17, 1998); Ryan v. Tad's Enters., Inc., 709 A.2d 682, 702 (Del. Ch. 1996), aff'd, 693 A.2d 1082 (Del. 1997); Kleinwort Benson Ltd. v. Silgan Corp., Civ. A. No. 11107, 1995 WL 376911, at *5 (Del. Ch. June 15, 1995); Cooper v. Pabst Brewing Corp., Civ. A. No. 7244, 1993 WL 208763, at *10 (Del. Ch. June 8, 1993); Hodas v. Spectrum Tech., Inc., Civ. A. No. 11265, 1992 WL 364682, at *3 (Del. Ch. Dec. 7, 1992); In re Radiology Assocs., Inc., 611 A.2d 485, 498 (Del. Ch. 1991); Neal v. Ala. By-Products Corp., Civ. A. No. 8282, 1990 WL 109243, at *9 (Del. Ch. Aug. 1, 1990), aff'd, 588 A.2d 255 (Del. 1991).

146. Kleinwort Benson, 1995 WL 376911.

147. See Peter V. Letsou, The Role of Appraisal in Corporate Law, 39 B.C. L. REV. 1121, 1123 (1998) (proposing that the appraisal remedy is designed "to reconcile differing shareholder preferences with respect to corporate transactions that alter the risk of the firm's shares”).

148. Borruso v. Commc’ns Telesystems Int'l, 753 A.2d 451 (Del. Ch. 1999). 
haphazard manner. The court relied solely on the comparable company method of analysis to derive "fair value." While the court did add a premium to the result of this analysis, it attempted to factor out any element of impermissible post-merger synergy value. ${ }^{149}$

\section{Ng: Achieving More Favorable Tax Treatment}

Ng v. Heng Sang Realty Corp. ${ }^{150}$ involved a squeeze-out merger of a privately held real estate company that, prior to the merger, was a subchapter $C$ corporation for federal tax purposes. The dissenting shareholder claimed that DCF projections should assume that the corporation would be treated, more favorably, as a subchapter S corporation, which the corporation evidently did convert to following the merger. Before the merger, however, subchapter S treatment was available only if all of the shareholders consented, and the dissenter refused to do so. The court concluded that subchapter S status was not part of the company's operative reality at the time of the merger, and therefore the company's "conversion to an S corporation cannot be considered for valuation purposes."151 Any gains attributable to altered tax status were not achievable for the company as operated and owned at the time of the merger, and arose solely by virtue of the accomplishment of the merger. Those gains were therefore properly excluded from "fair value."

\section{Gholl: Changing Both the Controller and the Manager}

On one possible reading, Gholl v. eMachines, which was discussed in Part IV.A.3, represents a category 2 case. ${ }^{152}$ In Gholl, the court used DCF analysis to award the petitioners an amount greater than the sale price of the company. The court determined "fair value" exclusively by reference to a DCF analysis; it did not attempt to construct a hypothetical third-party sale value. In that case, the winning bidder for the company was a founder and director, although not a controlling shareholder, but was assumed to have had the kind of informational superiority associated with a controlling shareholder. ${ }^{153}$ There was no indication that the bidder had any plans to operate the company differently following the merger. In fact, what the court took pains to do was to rely on the cash flow projections that best reflected merger date estimates of the company's future performance under a business plan adopted by the board shortly before the merger auction took place. We commend the Gholl opinion because of its attention to performing a correct DCF analysis based on the pre-merger plans of the company, and because it did not attempt to address concerns about potential abuse by the founder-director-bidder through reliance on a hypothetical third-party sale value.

In closing, we repeat our earlier contention that in these category 2 cases, paying the

149. Id. at 459. As discussed elsewhere, we are troubled by the ready acceptance of this form of "control premium” adjustment. As in Kleinwort, however, where the approach was first accepted, it appears to have been one that was advocated by both sides' valuation experts.

150. Ng. v. Heng Sang Realty Corp., Civ. A. No. 18462, 2004 WL 1151980 (Del. Ch. Apr. 22, 2004).

151. Id. at $* 6$.

152. Gholl v. eMachines, Inc., Civ. A. No. 19444-NC, 2004 WL 2847865 (Del Ch. Nov. 24, 2004) (declining to find that the actual sale price necessarily exceeded or equaled "fair value").

153. Id. at *15. 
minority shareholders the going concern value of the firm protects the interests of the minority shareholders. They are cashed out at the value of the shares had they been held indefinitely into the future. The characteristic feature of category 2 transactions is that whatever value enhancing changes are planned would not occur absent the merger. Whether it is the straightforward financial recapitalization, the reconsolidation of a failing subsidiary, or a change in management, the gains occur after the merger and would not occur without the merger. By adopting this resolution of category 2 cases, Delaware's appraisal rule encourages value enhancing transactions by not taxing the controlling shareholder with the burden of paying for a share of transactions or future returns that are not forthcoming at the time of the merger. This approach, however, may not appropriately extend to other categories of cases, including the one to which we turn next.

\section{Category 3 Cases: Controlling Shareholder Squeeze-Out Merger/“Fair Value” Equals Going Concern Value Under Controlling Shareholder's Post-Merger Management Plans}

Our third category of cases is the one to which the Delaware case law speaks the least clearly. At first glance, our suggestion that "fair value" should be determined by reference to corporate plans and assets that were not operationally in place within the enterprise before the merger seems to contradict the core precept that the dissenting shareholder is only entitled to the "value [of] what has been taken from the shareholder, i.e., the proportionate interest in the going concern." 154 If, as the cases hold, the corporation must be valued on the basis of "the operative reality on the date of the merger," 155 how, one might argue, can "fair value" be determined by reference to plans or assets not in place and operational at the time of the merger? Moreover, how can we assert that "fair value" may be determined by reference to plans or assets not in place at the time of the merger, when the Delaware Supreme Court has also pronounced that "where the corporation's going forward business plan is to retain the same management, a dissenting shareholder seeking appraisal may not seek to attribute value to an alternative cost pattern which may occur post-merger.”156

In fact, we believe that both finance theory and Delaware case law are consistent with our view that minority shareholders have a right to "fair value" that incorporates not only current assets but also future reinvestment opportunities, so long as those reinvestment opportunities reflect pre-merger plans or policies of the corporation and its controlling shareholder. From the perspective of finance, as described in Part III.A.3, the going concern value of a corporation includes not only the cash flow from existing assets, but also from the return on reinvestment opportunities. These reinvestment opportunities will not have been taken at the time of the merger, because they are to be funded with future free cash flow. Consequently, the assets purchased as part of the reinvestment opportunities will not exist at the time of the merger. However, these assets are as much a part of the present value of the corporation as are the value of the existing assets.

The consistency between our approach and Delaware case law draws upon three

154. Cede \& Co. v. Technicolor, Inc., 684 A.2d at 289, 298 (Del. 1996); see also Tri-Cont'l Corp. v.

Battye, 74 A.2d 71, 72 (Del. 1950).

155. Technicolor, 684 A.2d at 298.

156. Gonsalves v. Straight Arrow Publishers, Inc., 701 A.2d 357, 363 (Del. 1997). 
distinct lines of authority in Delaware appraisal law, each of which demonstrates that, in appropriate circumstances in which a controlling shareholder is acquiring the minority shares, the courts have interpreted "fair value" to include elements of value that arise from assets or plans that were not in place operationally at the time of the merger. Those three areas, as developed below, involve: (1) pro forma inclusion of assets not formally owned by the corporation at the time of the merger, but constructively attributed to the corporation because they had represented a corporate opportunity wrongfully usurped prior to the merger; (2) projections of post-merger returns in which actual costs are disregarded and excluded because they represent improper benefits to the controlling shareholder; and (3) operating improvements that the controlling shareholder implements following the merger but that do not depend causally upon the consummation of the merger. We review these three areas in order.

\section{Inclusion of Usurped Business Opportunities}

Cavalier Oil Corp. v. Harnett ${ }^{157}$ is the keystone, in fact, the sole component, in this category of authority. In that case, the Delaware Supreme Court was called upon to consider whether the "fair value" of the dissenters' shares could include their proportionate share of the value of a line of business that, they had claimed, would have belonged to the corporation at the merger date but for the controlling shareholder's wrongful usurpation of the opportunity to acquire the business. Rather than reject this claim on the ground that the line of business was not part of the corporation's "operative reality" at the time of the merger, the court agreed that the value of that line of business could be taken into account in determining "fair value," as if it had been formally part of the corporation's assets. ${ }^{158}$ The court approved this approach, moreover, even though no derivative suit challenging the usurpation had been filed at the time of the merger. ${ }^{159}$

This result in Cavalier did not require doctrinal contortion. If a business opportunity is wrongfully usurped before the merger, the corporation would have a claim to recover or impose a constructive trust upon that opportunity, a claim that could have been brought directly by or derivatively in the right of the corporation. ${ }^{160}$ That sort of claim is nothing more or less than an intangible asset of the corporation, capable of contributing to merger date "fair value" in the same way as other corporate assets. ${ }^{161}$ There may be

157. Cavalier Oil Corp. v. Harnett, 564 A.2d 1137 (Del. 1989)

158. Id. at 1143 .

159. Id. at 1143-44. The lower court had determined that the petitioner "did not have knowledge of the basis for the corporate opportunity claim prior to the institution of the appraisal proceeding."

160. See, e.g., Broz v. Cellular Info. Sys., Inc., 673 A.2d 148, 154-55 (Del. 1996); Guth v. Loft, Inc., 5 A.2d 503, 510 (Del. 1939).

161. See Nagy v. Bistricer, 770 A.2d 43, 55 (Del. Ch. 2000).

[I]n certain circumstances an appraisal proceeding will require the court to value breach of fiduciary duty claims . . . because those claims are part of the going concern value of the corporation whose entity value is being determined. Put a bit differently, because those claims are assets of the corporation being valued, the court must place a value on those assets in coming to a fair value determination.

Id. at 55-56. See also Bomarko v. Int'l Telecharge, Inc., Civ. A. No. 13052, 1994 WL 198726, at *2 (Del. Ch. May 16, 1994) ("[B]reach of fiduciary duty claims that do not arise from the merger are corporate assets that may be included in the determination of fair value.”); In re Radiology Assocs., Inc. Litig., Civ. A. No. 9001, 1990 WL 67839 (Del. Ch. May 16, 1990) (supporting the same principle); Porter v. Tex. Commerce 
reasons to discount the value of that claim to account for uncertainties and costs of recovery, ${ }^{162}$ but the mere fact that the underlying line of business was not owned by the corporation as of the merger date is not in itself a legal basis for excluding it from the determination of "fair value." 163

\section{Excluding Past or Projected Expenses}

Similarly, and despite the general rule against assessing "fair value” by reference to operating conditions not extant at the date of the merger, the Delaware courts have consistently shown a willingness to determine "fair value" on a pro forma basis that excludes the effects of controlling shareholder conduct considered to constitute a breach of fiduciary duty. Several examples make this clear.

Over 30 years ago, the court of chancery ruled that in determining the value of a film company's assets, a distribution fee payable to the corporation's controlling shareholder under a contract in force at the merger date should have been reduced from the contract amount (30\%) to a lower amount (12.5\%), because the controlling shareholder had failed to establish that the actual distribution fee was fair to the corporation. ${ }^{164}$ The Delaware courts have continually embraced this sort of adjustment ever since.

In Dobler, the vice chancellor approved and relied in part on a DCF valuation that had been adjusted to eliminate the effects of (1) management fees paid to the parent company for which no justifying evidence had been presented; (2) interest associated with an unexplained intercompany loan to the parent company; (3) an unsupported allocation of corporate overhead charges made by the parent company; and (4) rentals

Bancshares, Inc., Civ. A. No. 9114, 1989 WL 120358, at *5 (Del. Ch. Oct. 12, 1989) ("If the company has substantial and valuable derivative claims, they, like any asset of the company, may be valued in an appraisal.”); Francis I. duPont \& Co. v. Universal City Studios, Inc., 312 A.2d 344, 351 (Del. Ch. 1973) (adjusting asset value upward to offset excessive distribution fee charged by parent company).

162. See, e.g., ONTI, Inc. v. Integra Bank, 751 A.2d 904, 931-32 (Del. Ch. 1999) (citing Gonsalves v. Straight Arrow Publishers, Inc., Civ. A. No. 8474, 1996 WL 483093, at n.1 (Del Ch. Aug. 22, 1996)); see also Bomarko, Inc. v. Int'l Telecharge, Inc., C.A. No. 13052, 1994 WL 198726, at *3 ("[T]he value of the claims, if any, will be established through expert testimony in much the same manner that evidence typically is presented as to the value of other corporate assets.”).

163. We would reject the claim that a derivative action asserting the usurpation must have been on file before the merger in order to take the business opportunity into account in determining "fair value." As previously noted, Cavalier explicitly recited the fact that no such claims had been pending, yet the court included the value of the usurped line of business in determining "fair value." Cavalier Oil, 564 A.2d at 114344. It is true that in an analogous setting addressed in subsection 2 of this Part, the supreme court ruled in Gonsalves that "in the absence of a derivative claim attacking excessive compensation, the underlying issue of whether [executive compensation] costs may be adjusted may not be considered in an appraisal proceeding." Gonsalves v. Straight Arrow Publishers, Inc., 701 A.2d 357, 363 (Del. 1997). We believe, however, that the formal pendency of derivative proceedings pre-merger should not be dispositive, and that the Gonsalves court's reference to derivative claims is best understood as referring to viable derivative claims, regardless of whether they have been formally commenced. Of course, the absence of such proceedings pre-merger may well be probative of the lack of merit of such claims, absent some explanation (e.g., key facts were not disclosed to the shareholders before the merger, as was the case in Cavalier) for the fact that such proceedings had not been commenced.

164. duPont, 312 A.2d at 351 ("So far as this fee is concerned MCA had a fiduciary duty to Universal and, therefore, it has the burden of demonstrating that the fee was fair.”). 
associated with a sale to a wholly owned subsidiary of the parent company, and leaseback, of cellular sites and towers that the court found was "an inappropriate exaction by [the parent company] due to its corporate control.”165

In ONTI, the chancellor used a DCF analysis in which fees payable to the corporation by an affiliate of the controlling shareholder were adjusted from $20 \%$, the rate paid prior to the merger, to $40 \%$, a rate that the court found was required by the governing contract. ${ }^{166}$ In addition, the chancellor considered a further adjustment of future returns to reduce anticipated management fees to an affiliate of the controlling shareholder. The court declined to accept that adjustment only because the defendants offered persuasive evidence of the reasonableness of the management fee. ${ }^{167}$

In re Radiology Associates, Inc. Litigation approved the use of a DCF analysis that adjusted projected salaries to the officers of the corporation by backing out an amount deemed to constitute a return on equity rather than compensation because the salaries are proportional to share ownership. ${ }^{168}$

Nothing in these authorities, however, dispenses with the requirement that to accept a post-merger reconfiguration of assets or expenses in determining "fair value," the reconfiguration must be proven to be more than the product of speculation. Thus, for example, in Gonsalves, the Delaware Supreme Court upheld a ruling excluding a claim that the controlling shareholder's compensation as CEO was excessive, noting that there was no plan prior to the merger to adjust that compensation, and that "fair value" "do[es] not include the capitalized value of possible changes which may be made by new management."169 Even under a broad reading of the supreme court's language in Weinberger as discussed above, the benefits of an alternative method of operation that is neither proposed before the merger nor implemented thereafter should not be taken into account in determining "fair value" because they constitute "speculative elements of value” excluded by section 262(h).

\section{Including Combinatorial Merger Gains Not Dependent Upon the Consummation of the Merger}

In contrast, there are at least two relatively recent instances in which the Delaware Court of Chancery, in assessing “fair value," has included benefits arising from planned post-merger operating changes planned by the controlling shareholder before the merger.

The first such instance is the decision in ONTI. ${ }^{170}$ In that case, the controlling shareholder (Colkitt) completed the challenged cash-out mergers on August 30, 1995. ${ }^{171}$ Within a week, Colkitt announced one in a series of mergers that resulted in the merged

165. Dobler v. Montgomery Cellular Holding Co., Civ. A. No. 19211, 2004 WL 2271592, at *7, 16-17 (Del. Ch. Sept. 30, 2004).

166. ONTI, 751 A.2d at 917-18.

167. Id. at $918-19$.

168. In re Radiology Assocs., Inc. Litig., 611 A.2d 485, 490-91 (Del. 1991).

169. Gonsalves v. Straight Arrow Publishers, Inc., 701 A.2d 357, 362-63 (Del. 1997) (emphasis added); see also Hodas v. Spectrum Tech., Inc., Civ. A. No. 11265, 1992 WL 364682, at *4 (Del. Ch. Dec. 7, 1992) (finding no record support for the claim that the controlling shareholder's compensation as an officer of the corporation was excessive and declining to adjust that compensation for valuation purposes).

170. ONTI, 751 A.2d at 904.

171. Id. at 907 . 
companies being combined with a publicly traded company named EquiVision (renamed EquiMed in the merger). ${ }^{172}$ The dissenters argued that the merged companies' "fair value" should be determined by reference to their proportional contribution to the public company's stock price. The chancellor agreed, rejecting the controlling shareholder's argument that doing so would impermissibly incorporate elements of value arising from the accomplishment of the mergers.

The court's reasoning in ONTI drew upon Professor Coffee's article and upon the "cornfield" hypothetical discussed earlier. ${ }^{173}$ In its ruling, the chancellor emphasized that Colkitt maintained throughout the power to combine the merged companies with EquiVision. ${ }^{174}$ And although the court did not make this point in so many words, the opportunity for that combination arose because of Colkitt's controlling position with the merging companies. ${ }^{175}$ In any event, the bottom line reached in ONTI was the inclusion of a valuation that was dependent upon a market share price reflecting the benefits of the post-cashout merger combinations with the related businesses. Even so, after boldly applying the cornfield metaphor, the chancellor pulled back, attributing only a one-third weight to the value that gave effect to the post-merger combination (the "market-based" approach), and applied a two-thirds weight to the much lower DCF analysis (the "earnings-based" approach) done in the standard manner-namely, in a way that neglected the soon to be realized value of the post-merger combination.

We believe that an application of our approach would have resolved this anomalous and unsatisfactory conclusion. The source of the anomaly was the court's treatment of the standard DCF analysis, and particularly the treatment of the terminal value. The controlling shareholder's expert applied a growth rate in determining the terminal value that was based on the existing companies' historical non-merger growth rate. The dissenters' expert advocated that the terminal value be based on capitalizing the existing firm's earnings using a stock market multiple with the multiple based on that of comparable companies. The court rejected the analysis, concluding on the facts presented

172. Id. at 908 .

173. In particular, the chancellor recited a point presciently made by Wilmington practitioner David McBride, who offered the following illustration:

Let's suppose that you are the minority owner in the company that owns the cornfield and the majority stockholder and the members of the board say to themselves, boy, we really are underutilizing this asset. We ought not utilize this as a cornfield. The company is only selling at about $\$ 1$ per share. We can buy it at approximately that price and subdivide it or develop it and build buildings on it and sell those buildings or rent those buildings.

And the majority stockholder says to himself, yes, that's a great idea. Let's freeze out the minority. I'm going to capture all of that value for myself. And there's a freeze-out at a price that values the company by the majority stockholder at a price that reflects nothing but the value of that property as a cornfield.

I would suggest to you that a valuation of that company as of the date of the merger that doesn't take into consideration the nonspeculative possibilities of developing this cornfield into something other than a cornfield is not a realistic valuation of the company. The minority shareholders, under those circumstances, are entitled to a valuation that reflects the value of a company that owns a cornfield that can be developed into a major office center.

Id. at 910 (quoting Symposium, supra note 105, at 638).

174. Id.

175. ONTI, 751 A.2d at 910. 
that the companies were not comparable.

In our framework, once the court accepted the cornfield metaphor, viewing the case as falling in our category 3, any coherent DCF calculation would need to include a terminal value based on the future growth prospects and capitalization rates of the postmerger combination. Performed in this manner, the earnings-based approach would have provided a similar answer to that found in the market-based approach that was consciously based on the asset valuations in the post-merger combination. The courts' typical preference for using several different methods to determine an appraisal price makes perfect sense when the differences represent alternative calculations based on a finding as to the configuration of the company being appraised. Each method then represents a check on the other and another point estimate that can be averaged. In this case, the court's two methods, the earnings-based and market-based approaches gave radically different answers because they were based on conflicting theories as to the configuration of the company. As noted above, what was lacking was an earnings-based approach valuing the post-merger configuration of the company.

More recently, the court in In re Emerging Communications, Inc. Shareholders Litigation $^{176}$ determined fair value by reference to a business combination effected after the squeeze-out merger. In that case, the court considered whether a DCF valuation should incorporate post-merger savings anticipated to arise from the operational combination of the corporation and its controlling shareholder. ${ }^{177}$ The court's determination to consider such anticipated savings in determining "fair value" rested on three points.

First, the savings "were contemplated well before the going private merger."178 Thus, these savings, unlike the potential reduction of CEO compensation rejected in Gonsalves, were not speculative at the time of the merger. Second, the combinatorial benefits "could have been achieved without" accomplishment of the merger because the controlling shareholder "had the power to accomplish those savings without a business combination, such as by intercompany contractual arrangements." 179 Unlike the mergerrelated benefits at issue in Allenson, the cost savings anticipated in Emerging Communications did not require that the merger be accomplished first. ${ }^{180}$

Finally, and in light of the two previous observations, the court concluded that "the value achieved by [the controlling shareholder's] existing pre-merger ability to effect those cost savings was an asset of [the corporation] at the time of the Privatization merger. It therefore was a benefit in which all . . . stockholders, not just [the controlling shareholder], were entitled to share.”181

176. In re Emerging Commc’ns, Inc. S’holders Litig., Civ. A. No. 16415, 2004 WL 1305745, at*13 (Del. Ch. May 3, 2004).

177. Id.

178. Id.

179. Id.

180. In contrast, savings dependent upon going private, i.e., the elimination of costs of maintaining public company status, are dependent upon consummation of the merger, and should not be taken into account in determining "fair value." In Emerging Communications the court acknowledged this point. Had there been proof that the projections it relied on contained "going private" savings, the court would apparently have been prepared to reduce the projected returns accordingly. The court, however, found no proof that such savings were built into the projections. Id.

181. Emerging Commc'ns, 2004 WL 1305745, at *13 (citing Cede \& Co. v. Technicolor, Inc., 684 A.2d 


\section{Doctrinal Refinement of the Treatment of Merger-Related Gains In}

Assessing "Fair Value"

In our view, the court's treatment of the post-merger benefits in ONTI and Emerging Communications is extraordinarily insightful, and suggests a useful test for distinguishing between merger-related gains that should be excluded from "fair value" (the ordinary rule, we say) and those that should be included. In essence, what the courts in ONTI and Emerging Communications have done is articulate a standard grounded in the doctrine of corporate opportunity - the same doctrine that has permitted the courts, as in Cavalier, to include the value of operations that should, by reason of the doctrine, have been assets of the corporation at the time of the merger.

While it has been articulated in a variety of different ways, the corporate opportunity doctrine as explicated by the Delaware courts to determine whether a corporate fiduciary may take a business opportunity for his own benefit includes a number of relevant considerations: (1) Is the corporation financially able to exploit the opportunity?; (2) Is the opportunity within the corporation's line of business?; (3) Does the corporation have an interest or expectancy in the opportunity?; (4) Is the opportunity presented to the fiduciary in his individual and not his corporate capacity?; (5) Has the fiduciary employed the resources of the corporation in pursuing or exploiting the opportunity? ${ }^{182}$ This doctrinal framework works reasonably well in explaining the court's willingness in ONTI to give valuation effect to the post-merger business combinations affected by the controlling shareholder. The combinations with similar health care businesses were surely in the merged corporation's line of business; the opportunity for the combinations arose (i.e., was presented to the controlling shareholder) through his position with the merged companies; and above all, the combinations, and the resulting combinatorial value they created, involved a use of the merged companies' assets. Thus, the same sort of doctrinal considerations that lead to a finding of wrongful usurpation of a corporate opportunity point to the result reached in ONTI.

Applying the corporate opportunity standards to the post-merger savings discussed in Emerging Communications similarly confirms, indeed, almost tracks, the court's reasoning in that case. The post-merger gains fell plainly into the corporation's "line of business," since they arose directly from the combination of the corporation's operations with those of the controlling shareholder. The benefits arose from use of the corporation's assets, again, through their operational combination with the assets of the controlling shareholder. The opportunity arose because of the controlling shareholder's position with the corporation. Specifically, it had been contemplated by the controlling shareholder even before the merger. Finally, the gains were ones that the corporation itself could have exploited even without consummating the merger. As a result, the court concluded that the cost savings should have been incorporated into future cash flow projections of the corporation at the time of the merger, just as if the corporate opportunity doctrine had been applied.

Corporate opportunity principles, broadly defined to include the idea that use of the corporation's own assets creates a proprietary interest on the part of the corporation in the

289 (Del. 1996)).

182. See Broz v. Cellular Info. Sys., 673 A.2d 148, 155 (Del. 1996) (citing Guth v. Loft, Inc., 5 A.2d 503, 509 (Del. 1939)). 
resulting reinvestment opportunity, usefully define when post-merger enhancements should and should not be viewed as part of the nature of the enterprise for purposes of determining "fair value" in the case of a squeeze-out by a controlling shareholder. Gains that can only be created by the recapitalization or combination affected by the merger itself cannot and should not contribute to "fair value" for purposes of an appraisal proceeding. Moreover, where the corporation has a claim of entitlement to those gains under corporate opportunity standards, however, as where the gains arise in the line of the corporation's business, or are attributable to the corporation's assets as planned, or are in existence at the time of the merger, they are properly included within the enterprise, and the minority shareholders are entitled to a proportional share of such gains. This approach does not depend on a general phenomenon of asymmetric information, the point that Coffee relies upon to support the kind of result reached in ONTI, ${ }^{183}$ the extent and effect of which may be difficult to assess on the facts of any particular case. Our approach relies instead on circumstances that should be testable by evidence in actual cases, namely, whether the controlling shareholder has observably altered the conduct of the business of the corporation, and whether such an alteration can be said to have arisen from the premerger character of the company's business, or from the use of its assets.

\section{CONCLUSION}

Weinberger left us with a puzzle that gained prominence when Technicolor reiterated that the statutory exclusion of gains arising from the merger is a narrow one. This Article has offered a resolution of that puzzle. The resolution is consistent with the manner in which the courts have been dealing with the issue, but we believe it offers a principled method for differentiating between those gains that should be included in the going concern value and those that should not. We also offer specific suggestions on how to implement this approach in the context of a DCF analysis.

The cornfield metaphor usefully illustrates and supports our approach. Specifically, if the controller is planning to develop the cornfield into an office complex, the gains from that investment must be included in the value of the target company, even if the controller has made no move to implement that development plan before the merger. The reason for this is straightforward and follows from the very meaning of going concern value and DCF analysis. In the DCF method, the value of the company appraised is both the discounted free cash flows of the current assets and the discounted free cash flows generated by the reinvestment opportunities. That is, the cash flows that the target company does not pay out as dividends are available for reinvestment. If the target company, prior to the merger giving rise to appraisal, planned to turn the cornfield into an office complex, then that investment is a reinvestment opportunity, which is included in the present value of the growth opportunities.

We show that the corporate opportunity doctrine also provides a legal hook for resolving the valuation puzzle. The conversion of the cornfield into an office complex represents a corporate opportunity of the target company at the time of the merger. Although the corporate opportunity doctrine normally applies to the taking of an opportunity that has already occurred, the doctrine can easily be extended, without

183. See Coffee, supra note 12 , at $407-12$. 
requiring doctrinal gymnastics, to a taking that is planned at the time of the merger, but has not yet occurred.

In resolving the puzzle Weinberger poses, we can provide greater support for the court's long standing insistence on the logic of using going concern value over thirdparty sale value to measure fair value. The rationale for using third-party sale value is that going concern value does not provide sufficient protection against an opportunistic controller who would plan the minority shareholder squeeze-out to coincide with the discovery of a valuable reinvestment opportunity that it wants for itself. Our approach controls for potential opportunistic behavior by controllers. If planned prior to the merger, the reinvestment must be included in the value of the firm. The fact that the investment will not actually occur until after the merger is irrelevant. Indeed, none of the reinvestment opportunities, by their very definition, can already have been made as of the date on which the firm is to be valued. We believe that these reinvestment opportunities are at the heart of the opportunistic advantage that a faithless fiduciary could secure for itself.

Our approach also provides guidance on other issues related to the third-party sale value conundrum. In our three-part categorization of cases, the first category includes cases where there is a third-party offer. Our recommendation, in keeping with current Delaware case law and finance theory, is that the courts should determine fair value by using third-party sale value minus the value of the synergies arising from the merger. In these cases, assuming the sale process is effective and truly independent, then the minority shareholder does essentially receive third-party sale value when she does not dissent and foregoes the appraisal of her shares. Although the court may have a difficult time determining the amount to discount the sale price to net out synergistic values, the lack of precision is not instrumentally important. Once the rule is in place, rational minority shareholders will accept the sale price and not challenge the merger unless they can make a case that the sale process was ineffective and offer an alternative and reliable DCF estimate that provides a higher value.

Our second and third categories involve the squeeze-out of the minority shareholders by a controlling shareholder. In these cases there is likely no third-party offer. However, the minority shareholders are fully protected from opportunism, which is important in category 3 cases, because they can obtain their proportionate share of the value of any of the firm's corporate reinvestment opportunities. Although this sharing of value related to reinvestment opportunities may not favor the minority shareholders as much as a third-party sale value standard, we believe that a reinvestment opportunity sharing rule does meet the real concerns of those who advocate third-party sale value.

In all three categories, the court should apply going concern value that, as a remedy, protects the minority shareholders by making the merger Pareto-superior. Although the minority shareholders are not made better off, they are not made worse off either. They receive the value of what has been taken from them in appraisal. In the first category, where the sale process is effective, the minority shareholders should vote for the merger and receive the third-party sale value. In the second and third categories, an award of going concern value, which includes the reinvestment opportunities of the firm, fully protects the interests of the minority shareholders. 